\title{
Gravettian weaponry: 23,500-year-old evidence of a composite barbed point from Les Pres de Laure (France)
}

DOI:

10.1016/j.jas.2018.05.003

\section{Document Version}

Accepted author manuscript

Link to publication record in Manchester Research Explorer

\section{Citation for published version (APA):}

Tomasso, A., Rots, V., Purdue, L., Beyries, S., Buckley, M., Cheval, C., Cnuts, D., Coppe, J., Julien, M-A., Grenet, M., Lepers, C., M'hamdi, M., Simon, P., Sorin, S., \& Porraz, G. (2018). Gravettian weaponry: 23,500-year-old evidence of a composite barbed point from Les Pres de Laure (France): 23,500-year-old evidence of a composite barbed point from Les Prés de Laure (France). Journal of Archaeological Science, 100, 158-175.

https://doi.org/10.1016/j.jas.2018.05.003

\section{Published in:}

Journal of Archaeological Science

\section{Citing this paper}

Please note that where the full-text provided on Manchester Research Explorer is the Author Accepted Manuscript or Proof version this may differ from the final Published version. If citing, it is advised that you check and use the publisher's definitive version.

\section{General rights}

Copyright and moral rights for the publications made accessible in the Research Explorer are retained by the authors and/or other copyright owners and it is a condition of accessing publications that users recognise and abide by the legal requirements associated with these rights.

\section{Takedown policy}

If you believe that this document breaches copyright please refer to the University of Manchester's Takedown Procedures [http://man.ac.uk/04Y6Bo] or contact uml.scholarlycommunications@manchester.ac.uk providing relevant details, so we can investigate your claim.

\section{OPEN ACCESS}




\section{Gravettian weaponry: 23,500-year-old evidence of a composite barbed point from Les Prés de Laure (France)}

\section{Author Affiliation:}

Tomasso Antonin ${ }^{\mathrm{a},{ }^{*},}$ Rots Veerle ${ }^{\mathrm{a}, \mathrm{b}}$, Purdue Louise $^{\mathrm{c}}$, Beyries Sylvie $^{\mathrm{c}}$, Buckley Mike ${ }^{\mathrm{d}}$, Cheval Carole ${ }^{\mathrm{e}}$, Cnuts Dries, Coppe Justinn, Julien Marie-Anne ${ }^{\mathrm{f}}$, Grenet Michel, Lepers Christian ${ }^{\mathrm{a}}$, M'hamdi Mondher $^{\mathrm{h}, \mathrm{e}}$, Simon Patrick ${ }^{\mathrm{i}}$, Sorin Sabine ${ }^{\mathrm{c}}$, Porraz Guillaume ${ }^{\mathrm{j}}$

a: TraceoLab / Prehistory, University of Liege, Place du 20-Août 7, 4000 Liège, Belgium

b: Chercheur Qualifié du FNRS

c: Université Côte d'Azur, CNRS, CEPAM, Pôle Universitaire Saint Jean d'Angély SJA 3, 24, avenue des Diables Bleus, 06357 Nice Cedex 4, France

d: School of Earth and Environmental Sciences, Manchester Institute of Biotechnology, University of Manchester

e: CEPAM UMR 7264, Pôle Universitaire Saint Jean d'Angély SJA 3, 24, avenue des Diables Bleus, 06357 Nice Cedex 4, France

f: Unité Histoire naturelle de l'Homme préhistorique (UMR 7194), CNRS, MNHN, UPVD, 1 rue René Panhard 75013 PARIS

g: TRACES UMR 5608, Université de Toulouse - Jean Jaurès, Maison de la Recherche, 5, allées Antonio Machado, F 31058 Toulouse cedex 9.

h: ISAM, Kasserine, University of Kairouan, 1254 P13, Kasserine, Tunisia.

i: Musée d'Anthropologie préhistorique de Monaco, 56 bis Boulevard du Jardin Exotique, 98000 Monaco

j: CNRS, UMR 7041, ArScAn-AnTET, Maison de l'Archéologie et de l'Ethnologie, 21, allée de l'Université, 92023 Nanterre Cedex, France

*Corresponding Author, antonin.tomasso@ulg.ac.be, TraceoLab / Prehistory, University of Liege, Place du 20-Août 7, 4000 Liège, Belgium, +32 (0)4 366.58.39, ORCID iD 0000-0002-2120-3048

List: GP, LP and AT conducted the field research. AT performed the petrographic and technological study; VR and SB the use-wear analysis; VR and DC the residue analysis. LP studied the geomorphology and stratigraphy. MAJ performed the taphonomical and zooarchaeological analysis. SS performed the photogrammetry and 3D scanning. MM conducted the spatial analysis. PS performed the granulometric analysis; MB the ZooMs analysis. VR directed the SEM-EDS and CT-scan. MG made the drawings of the lithic implements. CC prepared the graphic reconstruction of the weapon. VR, JC, AT and CL designed and conducted the experiments. AT, GP, VR, and LP wrote the paper.

Abstract (250 words) 
Understanding hunting technology is pivotal in the study of adaptive and innovative forces that influenced the evolution of prehistoric societies. The manufacture, design and use of hunting weapons involve technical processes such as those of tool miniaturization, blank standardization and projection modes, but also influence broader demographic structures such as human subsistence strategies, territorial organization and socio-economic structures. Here we present a unique discovery from a newly discovered site at Les Prés de Laure (Var, France). Excavations revealed a multi-stratified openair site with archaeological units that were rapidly buried by the alluvium of the Jabron River. In a Gravettian layer dated between 25 and $23.5 \mathrm{ka}$ cal BP, within an area apparently dedicated to horse carcasses processing and consumption, 11 backed points were discovered in direct association with altered bone remains. Wear and residue analysis of the lithic backed points in combination with complementary experimental data converge to indicate that the find represents a bone point armed with lithic barbs and used as hunting weapon. This discovery provides new evidence for the manufacture and use of hunting weaponry in a Gravettian context and stimulates discussion on Paleolithic weapon function and design, offering a unique window into the characterization of prehistoric hunting strategies.

Keywords: Upper Palaeolithic, Western Europe, Composite technology, weapon design, Hunting weapon

Funding: Research at Les Prés de Laure is supported by the CEPAM-CNRS UMR 7264 in association with ArScAn-CNRS UMR 7041. Excavations are conducted with the agreement of the owner R. Rouvier. Field research and analyses are funded by the French Ministry of Culture (SRA PACA), the Municipality of Comps-sur-Artuby and the Museum of Prehistoric Anthropology of Monaco and have benefited from the Research Collective Program ETICALP (dir. D. Binder, CEPAM-CNRS UMR 7264). TraceoLab research is funded by the European Research Council under the European Union's Seventh Framework Programme (FP/2007-2013, ERC Grant Agreement Nr. 312283, V. Rots). Antonin Tomasso is indebted to the European Research Council and the University of Liège (Marie Curie BE-COFUND). Veerle Rots is indebted to the Fund for Scientific Research (FNRS-FRS). 


\section{Introduction}

How prehistoric hunting weapons were manufactured, designed and used is central to studies on the adaptive and innovative forces that influenced the behavioral evolution of our species (Straus, 1993). Such questions become prominent when discussing why and how bladelet technologies developed and generalized during the Upper Pleistocene (Elston and Kuhn, 2002). In Eurasia, bladelet technology dispersed during the Upper Paleolithic resulting in the production of miniaturized and standardized blanks (Bon, 2005). This miniaturization is classically associated with the development and diversification of weapons (Chesnaux, 2008; Crombé et al., 2001; Fischer, 1989; McDonald et al., 2007), even though numerous archaeological examples (Christensen and Valentin, 2004; Finlayson and Mithen, 1997) provide alternative interpretations (notably knives).

The study of hunting technology provides insights into broader processes related to the history of techniques, such as the process of miniaturization and the evolution of weapon delivery systems. Hunting equipment also depicts broader aspects of human life, such as the way past societies were organizing their subsistence, occupying their territories and managing their resources. The diversification through time of hunting weapons and their sophistication ultimately mirrors changes in the way prehistoric societies were socio-economically organized (Knecht, 1997).

Research on hunting technology requires a general reflection on the way weapons were designed, hafted and used. Apart from pointed wooden spears (Thieme, 1997), a weapon is composed of a projectile head (manufactured out of stone or organic material) that is secured by glue and/or bindings to a shaft manufactured from organic material. In the present study, we approach a composite weapon as one that requires multiple lithic insets or multiple materials combined in the projectile head (e.g. lithic and organic). The choice for a specific weapon design and a specific projecting mode depends on various factors such as the hunted prey and the hunting environment, the available raw materials, the technological traditions, as well as the beliefs of the society. However, the rarity of direct archaeological remains of composite tools hampers a solid understanding on how prehistoric hunting weapons were designed as well as how they varied geographically and changed through time.

So far, reconstructions of weapon design have mainly relied on the results of functional and experimental studies (e.g. Barton and Bergman, 1982; Chesnaux, 2008; Knecht, 1997; Nuzhnyj, 2007; O'Farell, 2004; Pétillon et al., 2011; Philibert, 2002; Plisson, 2005; Soriano, 1998; Weber, 2012; Yaroshevich et al., 2013). While convincing, such demonstrations are not direct evidence and are strongly influenced by comparisons with ethnographic and modern examples. Well-preserved Mesolithic specimens may also provide a source of inspiration (e.g. Bárta, 1989; Dolukhanov, 2008; Zhilin, 2015) as well as the rare Paleolithic examples (Abramova, 1984; Allain and Descouts, 1957; Leroi-Gourhan, 1983). In addition, due to taphonomic factors, post-depositional disturbances and/or excavation and analytical techniques, osseous and stone points have generally been dealt with separately in archaeological research (Nelson, 1997). Final interpretations systematically suffer from the lack of direct archaeological evidence for the combined use of both materials in a composite arrangement.

Discussions on the origin of composite projectile point technologies benefit from various but independent lines of evidence. Convincing functional evidence for the first stone points used as projectiles dates back to about $250 \mathrm{ka}$ in Europe (e.g., Biache-St-Vaast, France, Rots, 2013), at least about 100 ka in North Africa (e.g., Sodmein Cave, Egypt, Rots et al., 2011; Ifri N'Ammar, Morocco, Tomasso and Rots, 2017), over 77 ka in South Africa (e.g., Sibudu Cave, Rots et al., 2017) and around $70 \mathrm{ka}$ in the Near East (e.g. Umm el Tlell, Boëda et al., 1999). The earliest bone points date back to $c a$. 100ka ago in South Africa (Henshilwood et al., 2001) while appearing in Eurasia only around 40ka 
ago in the context of the Upper Paleolithic (Mcbrearty and Brooks, 2000). In Europe, the combination of osseous points and lithic microliths in composite projectile points is inferred from the early beginning of the Upper Paleolithic based on their association in several archeological records (Pétillon et al., 2011). Lithic and ivory fragments, found together embedded in a mammoth bone in the Yana site (Siberia), also appear as early evidence (ca. 30-35 ka cal BP) of the use of composite weapons for hunting megafauna (Nikolskiy and Pitulko, 2013).

In contrast with this inferred timing, the oldest currently known direct evidence of composite projectile weapons postdates the Last Glacial Maximum (LGM), and relates to an approximate period between $19 \mathrm{ka}$ and $15 \mathrm{ka}$ cal. BP. Discoveries were made at the sites of Pincevent (Leroi-Gourhan, 1983) and La Garenne (Allain and Descouts, 1957; Houmard, 2003) in France, Afontova Gora (Abramova, 1984; Graf, 2008), Taliskij (Gvosdover, 1952) and Kokorevo I (Abramova, 1982) in Siberia.

None of these finds has been the subject of a recent multidisciplinary study. At Pincevent, A. LeroiGourhan (1983) describes a fragment of a reindeer antler point with bladelets inserted in both grooves. The diameter of the antler point alone is around 5-6 $\mathrm{mm}$ and it measures $12 \mathrm{~mm}$ in diameter with the bladelets included. The bladelets are between 12 and $21 \mathrm{~mm}$ long. At la Garenne, the reindeer antler points have only one groove (Houmard and Jacquot, 2009). In one of these antler points, several fragments of stone elements were identified.

The composite point of Afontova Gora is poorly documented: Z. Abramova (1982) provides secondhand information, with reference to V.I. Gromov, but indicates that the described point was lost. For the find of Talitskij, M.D. Gvosdover (1952) documents the insertion of seven backed bladelets, poorly standardized in length, on both sides of a reindeer antler point. Finally, for Kokorevo I, Z. Abramova (1982) identifies reindeer antler points with a single groove. In two of these points, backed bladelets have remained hafted in the groove ( 1 backed bladelet for the smallest fragment, 8 backed bladelets for the longest point) and form a continuous cutting edge that emerges no more than $1 \mathrm{~mm}$ from the groove.

All these post-LGM examples show a relative homogeneity: they all associate a reindeer antler point with stone backed bladelets hafted in one or two rows. These bladelets function only as cutting edges and not as barbs that retain the weapon in the prey. Nonetheless, during the Magdalenian, especially from 16 to $13.5 \mathrm{ka}$ cal. BP, another type of projectile point is represented by barbed osseous points (Pétillon, 2016). Also use-wear analysis on microliths suggests the use of lithic barbed points at some Upper Paleolithic sites (Yaroshevich et al., 2013). The first direct evidence of barbed composite points dates to the Mesolithic with several discoveries, notably in northern Europe (Kozlowski, 2009; Larsson and Sjöström, 2010; Peterson, 1951; Svoboda et al., 2007). At these sites, designs with "cutting edges" occur in association with "barbed" designs. One or two rows of barbs (5 to 6 barbs per point in known examples) are inserted into osseous or wooden points. The point of Oleni Ostrov is original in its design with only one row of bladelets forming a continuous cutting edge on a selfbarbed wooden point (Kozlowski, 2009). Use-wear analysis also confirms the use of barbed composite points in the Mesolithic (Chesnaux, 2014, 2008).

A discovery made at the site of Les Prés de Laure in Comps-sur-Artuby (Var, France) provides new insight into Paleolithic weaponry. A set of 11 backed points was found in association with osseous fragments in a layer dated to $25-23.5 \mathrm{ka}$ cal. BP. Here we present the results of a multidisciplinary study of this find involving residue, use-wear and technological analysis combined with experimentation, a micromorphological study, spatial analysis, and a multi-proxy analysis of the osseous remains. We propose that the association of the different artefacts reflects an in situ 
degradation of a composite barbed point, representing the oldest and the soundest evidence of composite projectile points known to date.

\section{Material and methods}

\subsection{Context and occupations at the site of Les Prés de Laure, France}

The Liguro-Provençal arc, a narrow corridor south of the Alps, plays a pivotal role in discussions on the processes of cultural and demographic interactions between Western and Eastern Europe (Naudinot et al., 2017; Porraz et al., 2010). Importantly, this region is of interest to investigate technological changes that happened before and after the Last Glacial Maximum (LGM), which is represented archaeologically in this region by the succession from the Gravettian to the Epigravettian techno-complexes. Many sites of this period are scattered throughout the region, including the wellknown painted cave of Cosquer and the Balzi Rossi complex where several burials and Venus figurines have been discovered.

In 2012, a new research program focusing on Alpine prehistoric occupations led to the discovery of Les Prés de Laure (Porraz et al., 2014), an open-air site located at an altitude of ca. $850 \mathrm{~m}$ asl. and ca. $50 \mathrm{~km}$ from the Mediterranean coast (fig. 1), in the middle valley of the Jabron river (Costa et al., 2015). Excavated since 2013, several occupations attributed to the late Gravettian and early Epigravettian have been recognized. The site formed by a succession of fine alluvial silts that contributed to the excellent preservation of the archaeological remains, notably in terms of spatial organization.

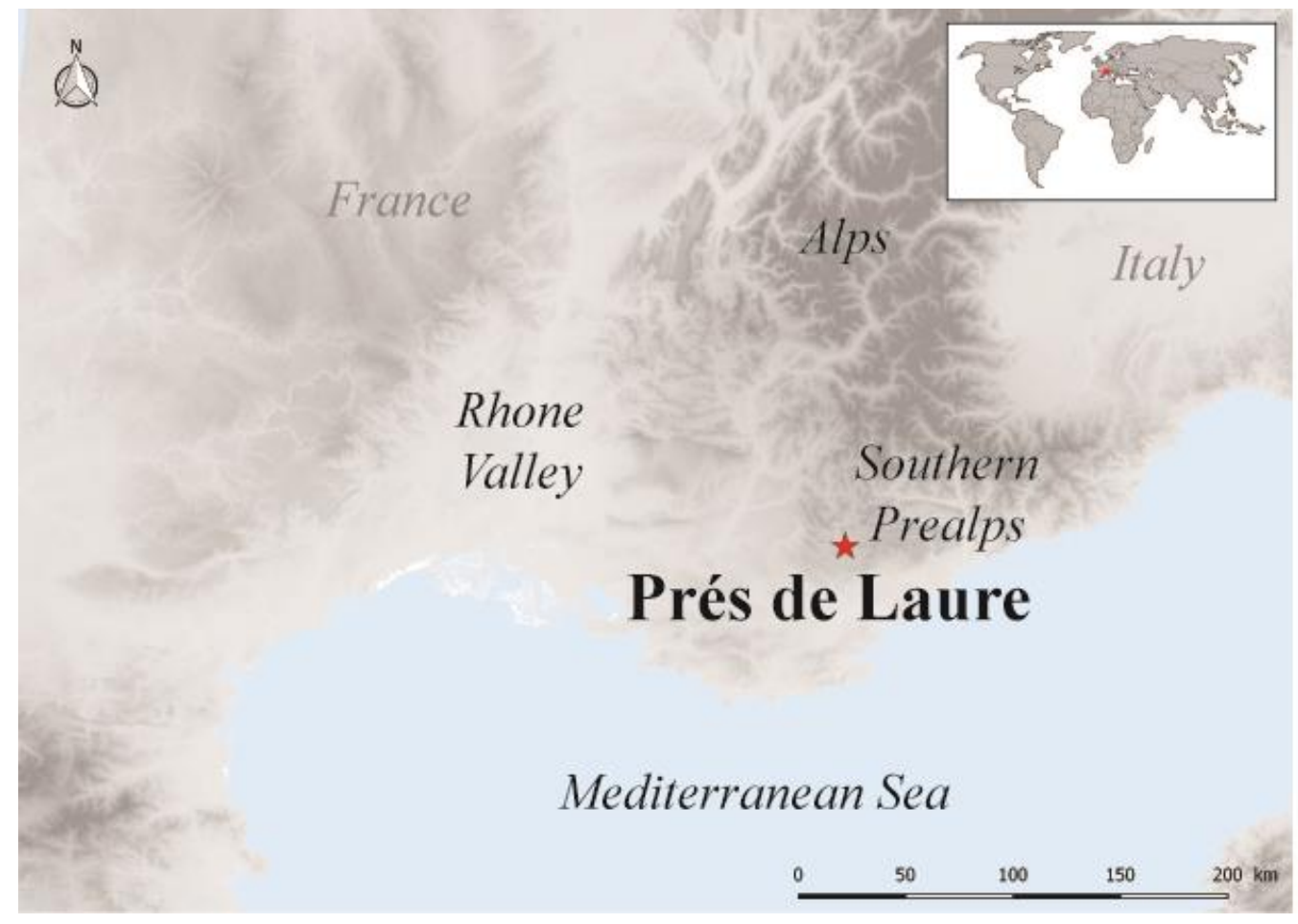

Fig. 1: Location of Les Prés de Laure (Var, France).

Sector 5 of Les Prés de Laure was excavated over a surface of $9 \mathrm{~m}^{2}$ (fig. 2). The stratigraphy comprises 13 stratigraphic units (SUs) over a thickness of ca. 1m (fig. 3). These alluvial deposits overlie a gravelrich bed (ancient riverbed) on top of the limestone and glauconious bedrock. Archaeological artifacts are present in five of the 13 SUs. This study focuses on the SU L17, which presents characteristics of an ancient fluvial paleosoil. 


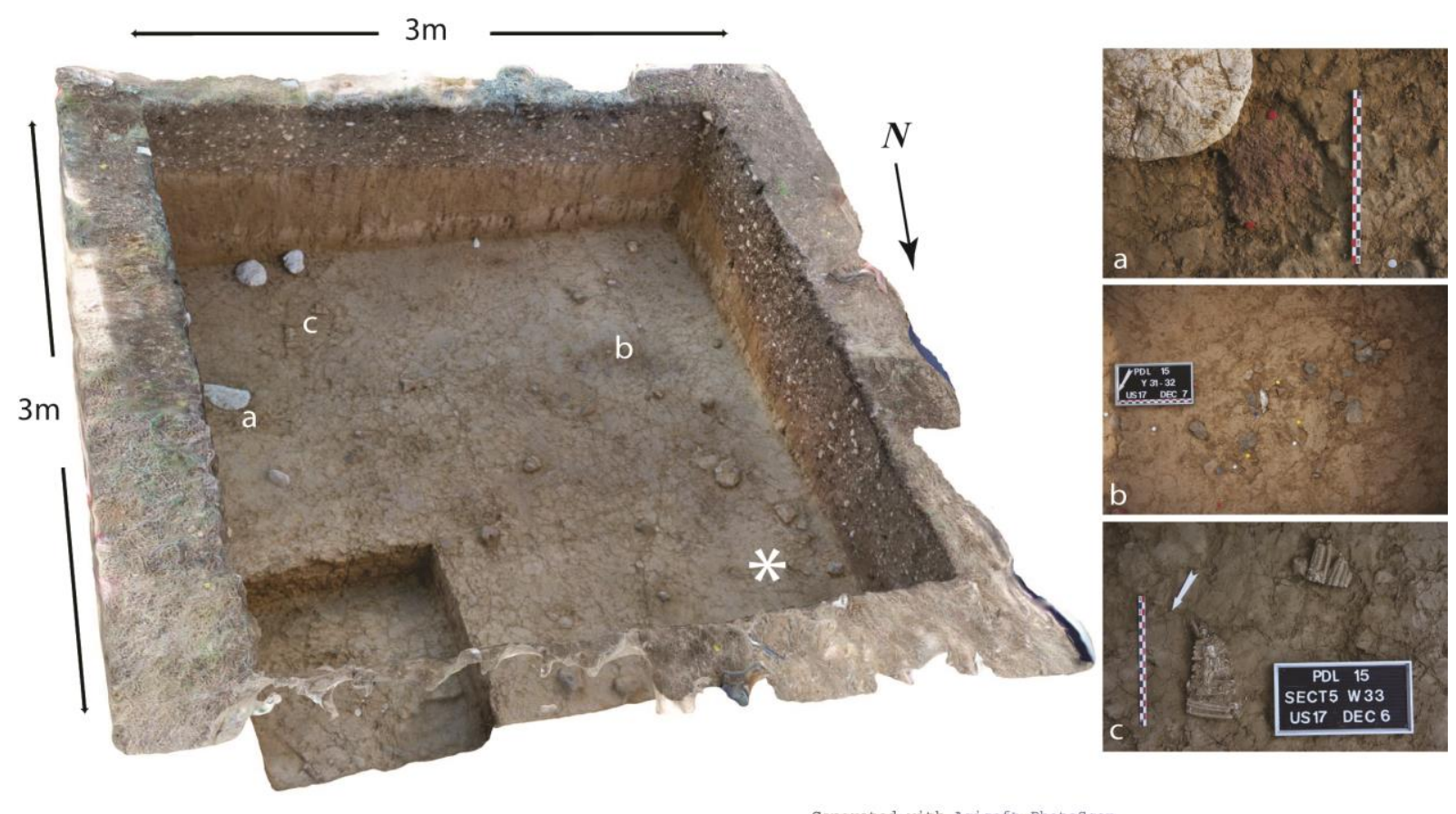

Fig. 2: Les Prés de Laure: archeological surface of the SU L17 (sector 5) as exposed in 2016 with details on (a) an in situ concentration of iron oxides $(b)$ a concentration of flakes and $(c)$ an intentionally broken horse mandible. The * indicates the location of the discovered 11 lithic backed points
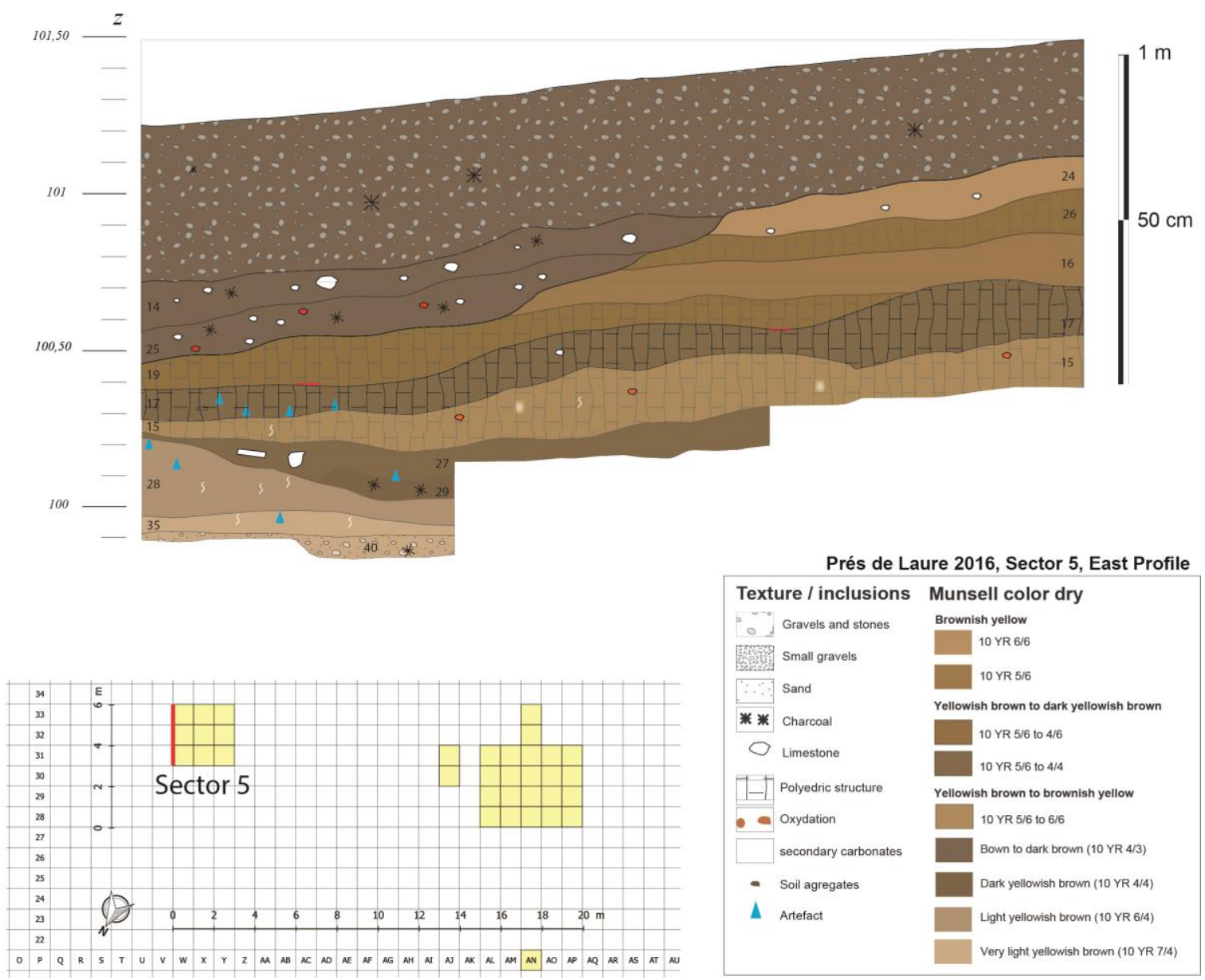

\begin{tabular}{|c|c|c|}
\hline \multirow{2}{*}{\multicolumn{2}{|c|}{ Texture / inclusions }} & \\
\hline & & Munsell color dry \\
\hline 0 & Gravels and stones & Brownish yellow \\
\hline 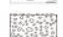 & Small gravels & $10 \mathrm{YR} 6 / 6$ \\
\hline Fimetis & & 10 YR $5 / 6$ \\
\hline$\because \therefore$ & Sand & Yellowish brown to dark yellowish brown \\
\hline * * & Charcoal & Che \\
\hline 0 & Limestone & \\
\hline T- & Polyedric structure & Yellowish brown to brownish yellow \\
\hline 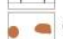 & Oxydation & 10 YR 5/6 to 6/6 \\
\hline & secondary carbonates & Bown to dark brown (10 YR 4/3) \\
\hline - & Soil agregates & Dark yellowish brown (10 YR 4/4) \\
\hline $\boldsymbol{\Lambda}$ & Artefact & Light yellowish brown (10 YR 6/4) \\
\hline & & Very light yellowish brown (10 YR 7/4) \\
\hline
\end{tabular}

Fig. 3: East profile of sector 5 of Les Prés de Laure. 
SU L17 has a relatively low artifact density ( 0.62 pieces per L of sediment). Various archeological items were plotted, predominantly consisting of lithic remains $(n=675)$ together with a few limestone blocks $(n=10)$ and faunal remains $(n=38)$. In addition, we identified 8 areas with reddish sediment (up to $200 \mathrm{~cm}^{2}$ ). Two horse teeth were selected for AMS radiocarbon dating and provided ages of 25488 24731 cal. BP (20840 +/- 100 BP, Poz-77717) and 23981-23271 cal. BP (19610 \pm 120 BP, Poz-87865). Dates were calibrated using the IntCal13 curve on Oxcal with a 2 sigma range (Reimer et al., 2014).

The SU has a thickness of 15 to $20 \mathrm{~cm}$ and its micro-topography indicates a slight slope toward the north-east. It is composed of superposing fine alluvial silts (2-4 cm thick) (fig. 4) in which pedological and/or pedo-climatic processes developed (e.g. platy to sub-rounded soil structure, in-situ vegetation growth) and also remains of anthropogenic activities were visible (burnt fragments of soils and organic matter) (S1). The SU is totally de-carbonated and eluviated as a result of repeated freezing/thawing processes and snow melting, but no traces of soil movement were noticed. In the upper part of SU L17, where most of the anthropogenic features were encountered, increased traces of biological activity and a well-developed soil structure suggest temporary mild conditions associated with soil pedogenesis and reduced flooding. The latter are indicators of landscape stability, favorable to human settlement in the valley.
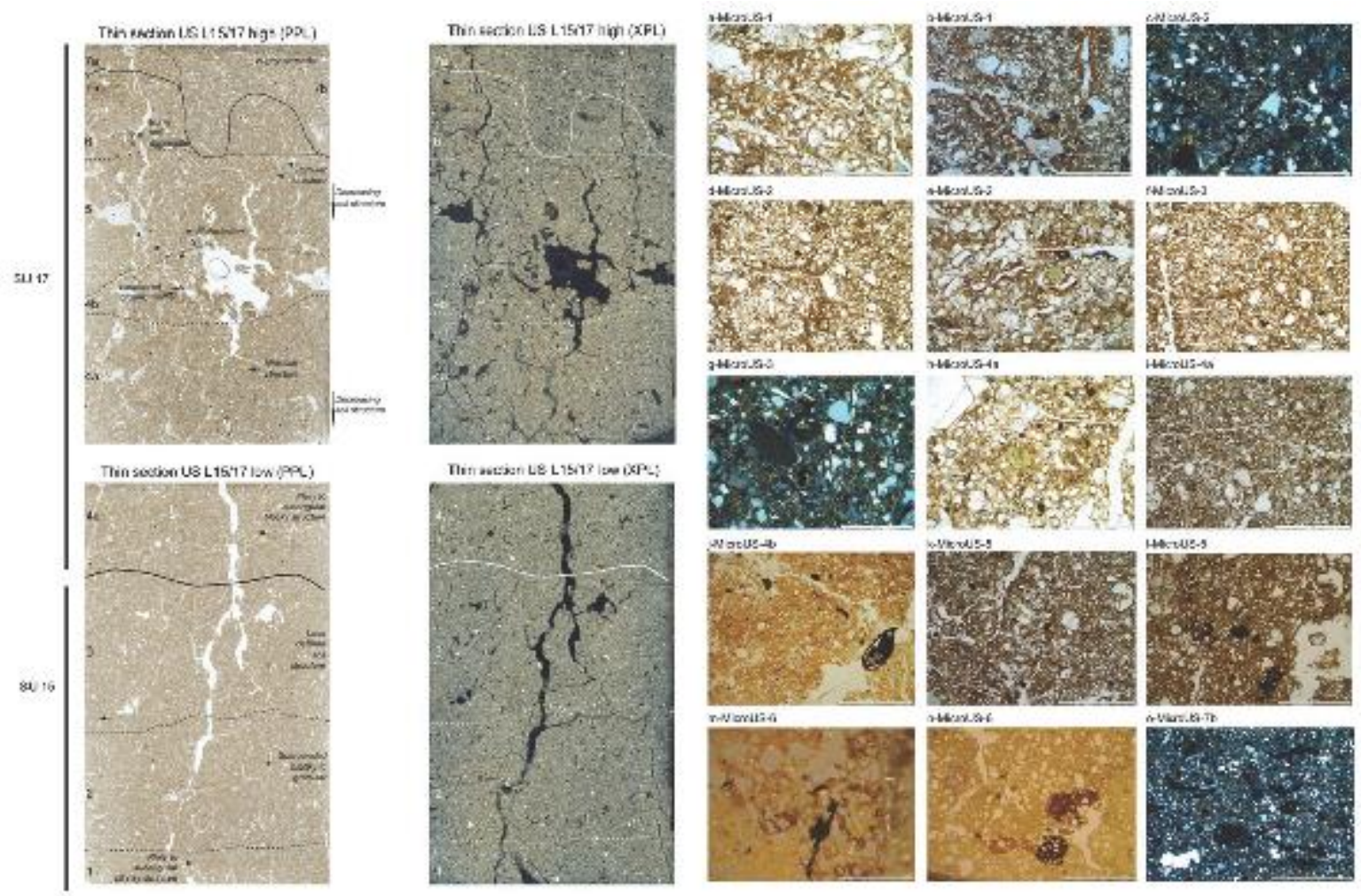

Fig. 4: (left) Scan of the two thin sections with the identification of microstratigraphic units and pedological features. (right) Microphotographs of some of the sedimentological and pedological features observed in stratigraphic unit L15 and L17: plane polarized light (PPL), crossed polarized light (XPL), incident light (IL). (a) fine unaccommodated planar voids defining a sub-angular blocky structure (PPL), (b) illuviation features with oxidized clay coatings and dusty clayey coatings $(P P L),(c)$ granostriated b-fabric (XPL), (d) granular structure with accumulation of fine material around the aggregates maybe as a result of stress and pressure (PPL), (e) dusty and oxidized clay coatings in irregularly shaped voids (PPL), $(f)$ partly accommodated planar voids defining a sub-angular blocky structure (PPL), $(g)$ granostriated b-fabric $(X P L),(h)$ frost-shattered grain of glaucony in a sub-angular blocky structure (PPL), (i) partially accommodated planar voids in a subangular blocky structure (PPL), (j) amorphous organic matter dispersed in the soil and deformed organic material, ( $k$ )Planar voids cutting through a channel infilling (PPL), (l) Irregular Fe/mn nodules (PPL), $(m)$ Burnt fibers of organic matter in orthic/disorthic rubified soil aggregate (IL), (n) disorthic nodules of burnt material displaced on a low distance by biological activity (IL), (o) vughy structure with numerous planar voids in washed sediments. 
Artefacts were recovered over the entire excavated area and their orientation and inclination and the absence of a size-related distribution indicate that no major post-depositional disturbance took place (S2). We plotted 267 lithic pieces and collected 343 fragments and flakes under $2 \mathrm{~cm}$ during sieving. The techno-economic analysis allows estimating of a high "minimum number" of blocks (Porraz, 2008). The assemblage (S3) reveals the import of isolated products and few in situ knapping events. We argue that this lithic assemblage reflects activities oriented toward the consumption of tools and not toward their manufacture or replacement. Most pieces document the exploitation of local chert resources (mainly pebbles from the Jabron river nearby). Only one burin spall and one blade document long-distance circulations, with cherts originating from the Oligocene formation of the Alpes-deHaute-Provence, ca. $70 \mathrm{~km}$ to the west. The lithic assemblage documents a low number of formal tools. We identified 13 backed points. Most of them (11) are backed points with oblique truncation, found in association with osseous fragments and these are the subject of the following study. The two other points differ in their morphology and were found separately. It concerns two distal fragments of backed points with inverse retouch at the apex, traditionally classified as microgravette in Gravettian contexts. The use-wear analysis of these two fragments revealed impact-related damage that is suggestive of an axial hafting.

Similar to the lithic remains, the faunal remains (S4) are distributed over the entire excavated area. They are however more numerous and larger in size towards the southern and eastern part of the excavation, and mostly chips of bone or tooth of ca. $1 \mathrm{~cm}$ long were found in the north-west part. Faunal remains are intensively altered and fragmented, but dental remains are relatively well preserved. Morphological identification allows the recognition of only one species in the faunal assemblage of SU L17: Equus ferus, i.e. horses. Four dental groups, composed of at least 12 teeth belonging to three individual horses, are present in the studied assemblage. Eruption and wear stages as well as the stage of dental development and the crown height measurements allowed estimating the age at death of the horses (Fernandez and Legendre, 2003). They belong to different age classes: a young of ca. 2 years old, an adult of 6.5 to 8.5 years old and an old specimen of at least 16 years old. Preservation of the remains was insufficient to allow observing cut marks or other kinds of anthropogenic marks on the bones; however, evidence of intentional bone breakage is identifiable on the dental remains of at least one equid mandible (fig. 5). Combined with other archaeological evidence, this seems to indicate that the area was dedicated to the processing of horse carcasses and that in situ consumption occurred here. 


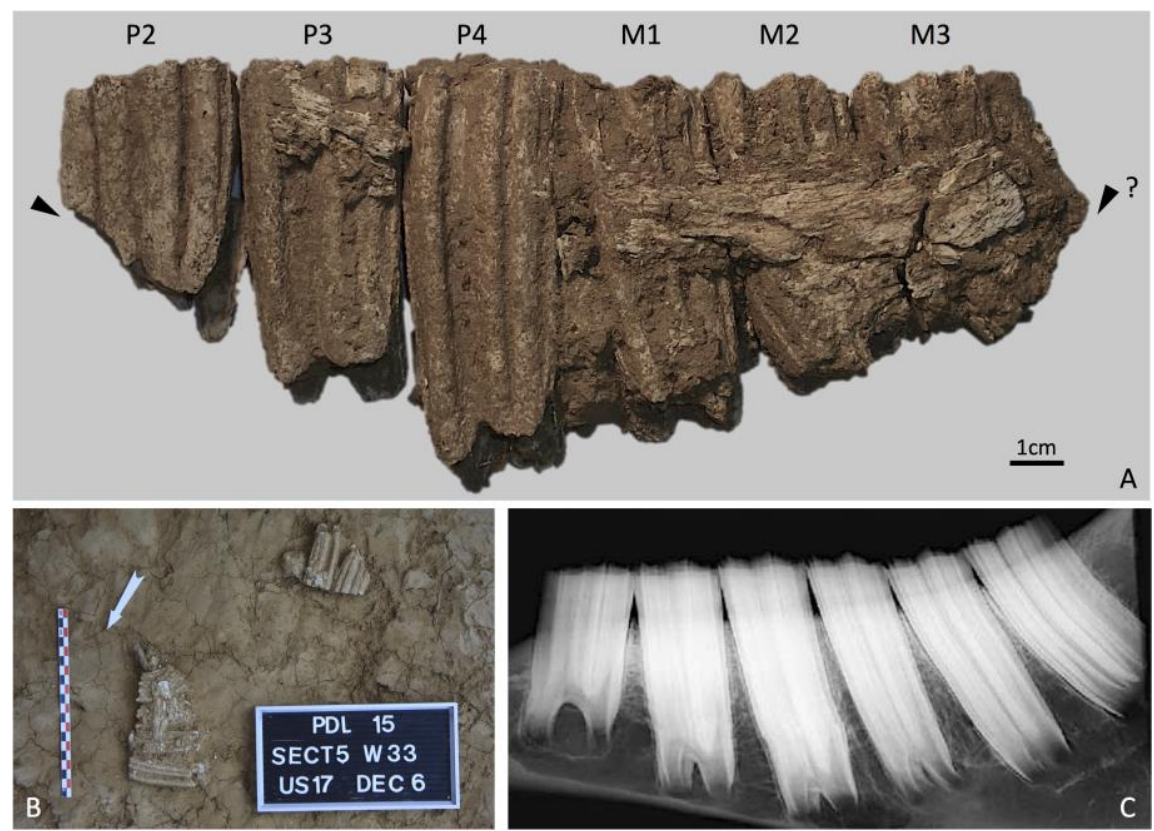

Fig. 5: Lower tooth row from a horse mandible showing damage likely resulting from intentional percussion (A) the arrows indicate the location of the fractures on the P2 and M3 teeth resulting from the possible intentional breakage of the mandibular bone $(B)$ fragments of the same mandible during excavation $(C)$ modern comparative reference of a complete tooth row from an unmodified horse mandible (modified from Hoppe et al., 2004).

While excavating the SU L17, we noticed a peculiar concentration of 10 small lithic backed points in an area of ca. 1/16 of $\mathrm{m}^{2}$ (fig. 6). One additional backed point was discovered while sieving the sediment of the same $1 / 4 \mathrm{~m}^{2}$. The backed points found in situ were distributed along both sides of altered fragments of an elongated osseous remain of ca. $11 \mathrm{~cm}$ long with a north-west orientation; two backed points were directly in contact with it. All pieces were vertically distributed over a thickness of less than $10 \mathrm{~mm}$. The density, the association and the organization of lithic and osseous remains in a sedimentary context that suffered little disturbance suggests the set of artefacts formed a single implement.

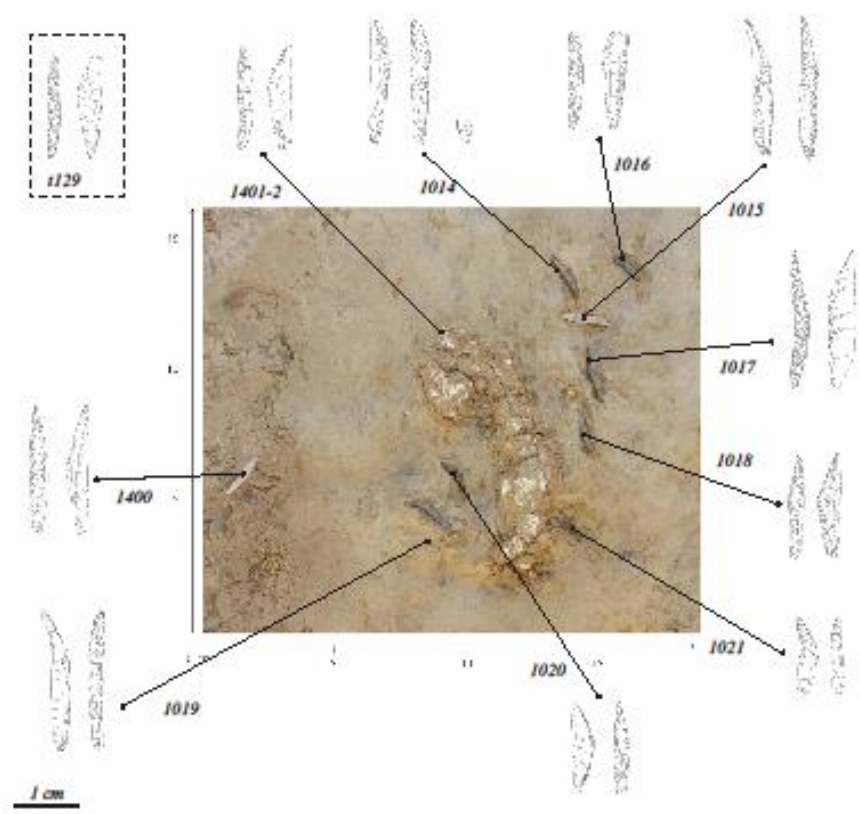

Fig. 6: Find context and details of the backed points found during excavation in close association with an osseous element (SU L17 of Les Prés de Laure). 


\subsection{Methods}

A multidisciplinary analytical study was performed on the finds integrating an analysis of technology, raw material, residues and use-wear combined with experimentation and a spatial analysis. In addition, a study of the micromorphology, the bone fragments and the fauna was performed. Detailed methods are presented in SI (S5). Only essential information is provided below.

A $500 \mathrm{~cm}^{2}$ and $6 \mathrm{~cm}$ thick block of sediment surrounding and including the osseous fragments and the lithic implements was plastered in the field and excavated under controlled conditions in the CEPAM laboratory. 3D scanning and photogrammetry were performed before and at several intervals during the excavation. Excavators wore starch-free gloves to prevent contamination (i.e. residues).

ZooMS collagen fingerprint analysis (Buckley et al., 2009) was carried out on a small bone chip of the osseous element sampled in the field with sterile tools. Bone remains were further examined in more detail using a stereoscopic and metallurgical microscope, a scanning electron microscope coupled with energy dispersive spectrometry (SEM-EDS IT-100) and a micro-CT-scan.

The backed points were studied successively for residues, technology, use-wear traces and raw materials. Residue analysis was performed in two phases: an in-situ observation of the residues on the stone tool surface followed by an analysis of extracted residues (Cnuts and Rots, 2017). In-situ observation of residues was performed with a stereomicroscope, a macro-zoom microscope and a reflected-light metallurgical microscope with rotating polarizers and DIC. Extracted residues were observed using a transmitted light microscope with rotating polarizers and DIC. During use-wear analysis, attention was devoted to all types of traces including fractures, scarring, polish, striations and rounding. All interpretations relied on the combination of different wear traces (e.g., fractures, scarring, striations, rounding, polish) in specific patterns and no interpretation relied on one wear type only (Rots and Plisson, 2014). Specific terms are used for the description of the fractures and to avoid terminological ambiguity (Coppe and Rots, 2017), we define them here. A "spin-off" is defined as a cone-initiated scar starting from an earlier fracture surface and terminating on a ventral or dorsal surface or a lateral edge. A "burination" is defined as an elongated bending initiated fracture starting from one edge and terminating on the opposite edge. "Crushing" is defined as multiple very small scars varying in orientation and initiation and showing abrupt terminations (step, hinge).

\section{Results}

\subsection{The lithic implements}

The 11 backed points (fig. 7) are made from two different types of chert (S6): Valanginian's chert available less than $1 \mathrm{~km}$ to the south $(\mathrm{n}=7)$ and a tertiary lacustrine chert that can be found in the nearby Jabron River $(\mathrm{n}=3)$. Both petrographic facies show a very low internal variability, which suggests the backed pieces may originate from only two blocks. 


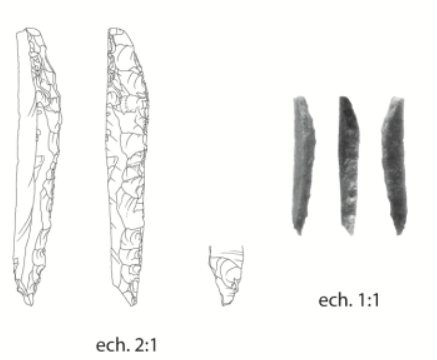

PDL15.1014
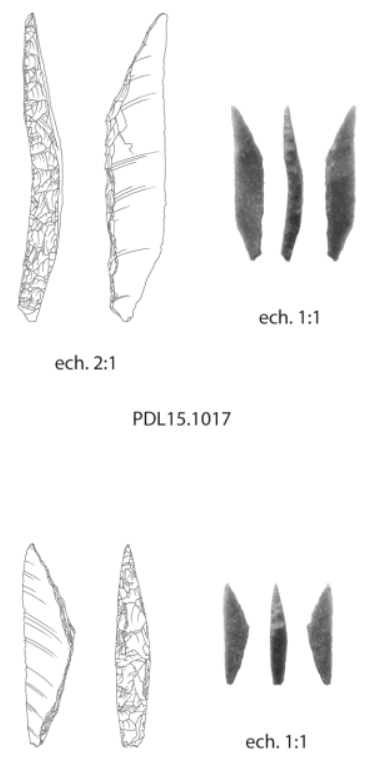

ech. 2:

PDL15.1020

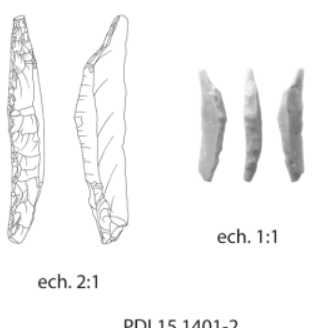

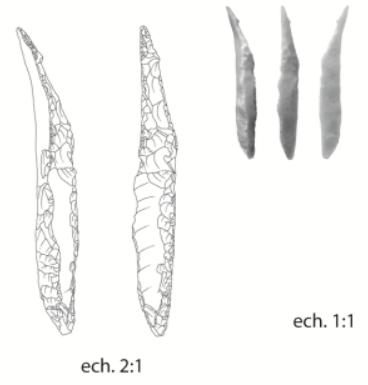

PDL15.1015

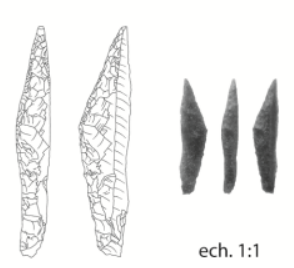

ech. 2:1

PDL15.1018
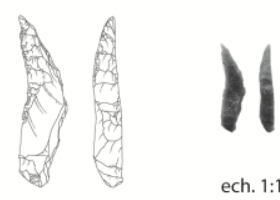

ech. 1:1

ech. 2:1

PDL15.1021
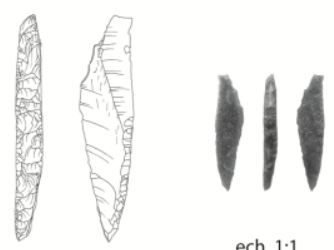

ech. 1:1

ech. 2:1

PDL15.t129

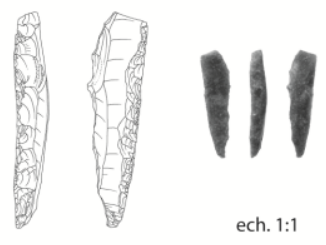

ech. 2:1

PDL15.1016

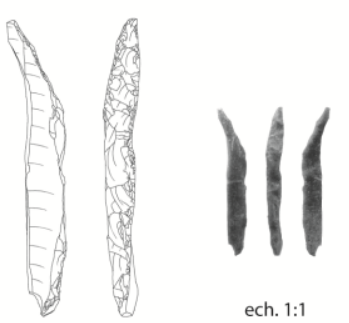

ech. 2:1

PDL15.1019

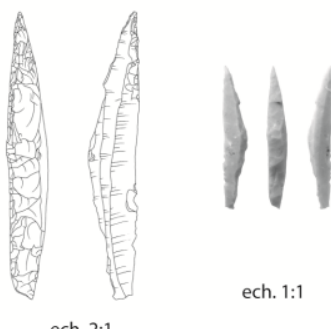

PDL15.1400

Fig. 7: Drawings (scale 2:1) and pictures (scale 1:1) of the 11 backed points found concentrated in a zone smaller than $500 \mathrm{~cm}^{2}$. Noteworthy is their homogeneity in terms of technology, morphology and dimensions.

The homogeneity between the 11 backed points is striking and concerns their technology, their morphology and their dimensions (S7). They are all manufactured on bladelets that were detached from the edge of flakes following a unidirectional reduction sequence with, most likely, the use of a 
soft hammerstone (fig.8a). Most bladelets have a twisted morphology $(n=8)$ and a straight $(n=8)$ or slightly curved profile $(n=3)$. The armatures associate a straight backed edge (back) with a distal oblique truncation, resulting in a triangular tool shape. All points share common metric characteristics with regard to: (1) the inflexion point that characterizes the angle between the back and the truncation (average: $\left.149.2 \pm 8.1^{\circ}\right)$; (2) the point $\left(26.7 \pm 4.5^{\circ}\right)$; (3) the thickness $(1.9 \pm 0.4 \mathrm{~mm})$ and (4) the width ( $3.5 \pm 0.5 \mathrm{~mm})$. Only the length displays some variability (from 12 to $22 \mathrm{~mm}$ ).

The straight back and the truncation were manufactured by direct percussion (fig. $8 b$ ). The truncation systematically presents regularization by a crossed retouch, which suggests that special attention was paid to its final shaping (fig.8c-d). The position of the back on the bladelet (i.e., lateralization) is variable and is situated either to the right $(n=5)$ or to the left $(n=6)$. The bladelets show a twist over their longitudinal axis that is intentional (fig.8e) and a correlation seems to exist between the direction of the twist and the position of the back (with one exception). This correlation finds technical reasons, considering that the knappers preferentially shaped the naturally concave edge to prepare the back. The cutting edge is convex $(n=5)$ or straight $(n=6)$ in plan view and rarely retouched (fig. $8 f)$. The few modified pieces $(n=4)$ show the application of marginal nibbling (i.e., small and regular) retouch restricted to a portion of the cutting edge.
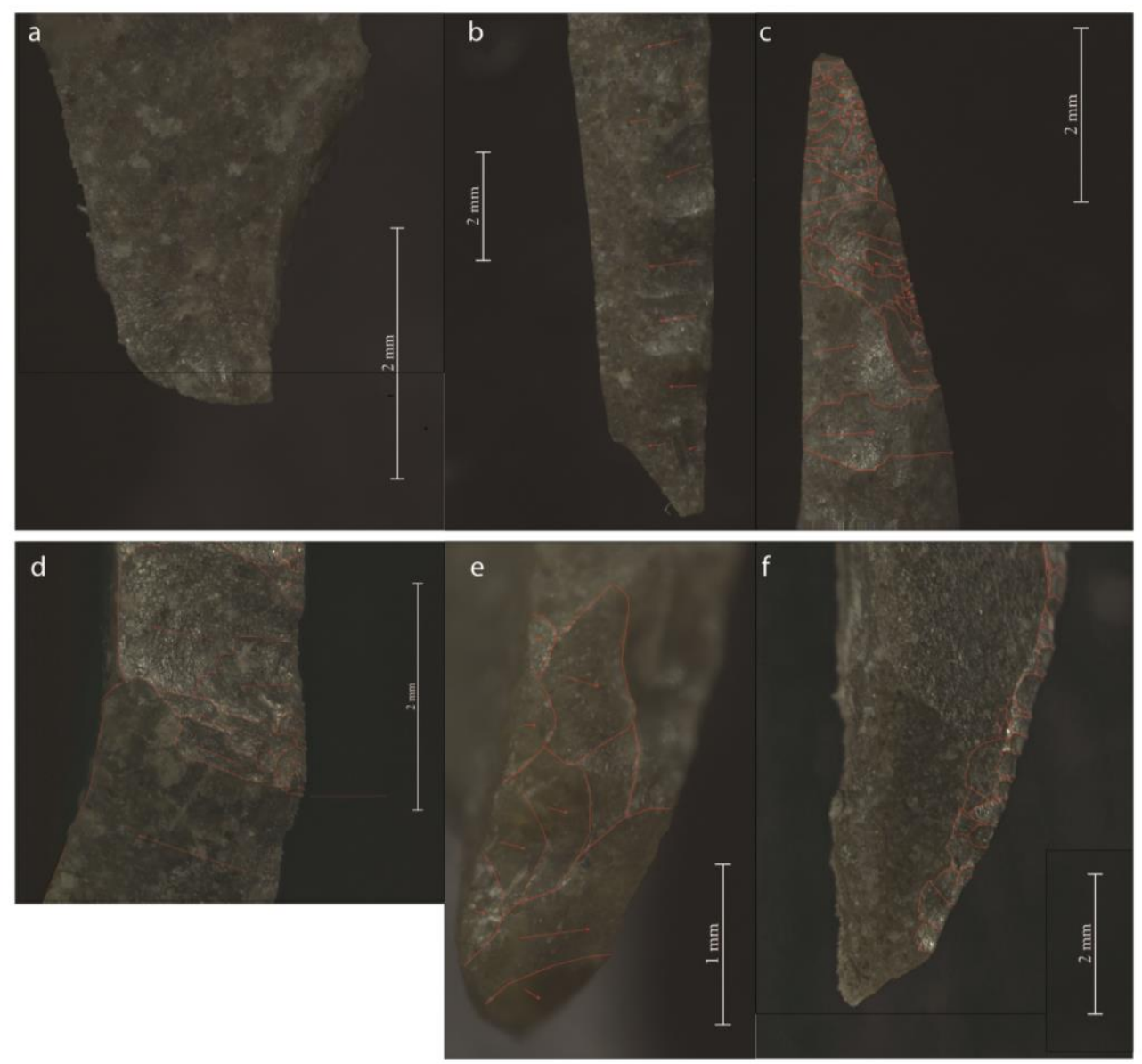

Fig. 8: Production method of the backed points. (a) The hypothesis that a soft hammerstone was used for the production of the blanks is based on the presence of two technical stigmata (a defined contact point and a poorly developed bulb) preserved on the remaining proximal part of the bladelet (PDL15.1016); (b) The backed edge is shaped by direct retouch, which is characterized by the presence of large, deep, and irregular removals (PDL15.1014); (c) The truncation on the distal tip presents a crossed retouch that indicates the use of anvil percussion (PDL15.1018); (d) Detail on the interface between the back (bottom) and the truncation (top), showing a change in the retouch modalities (PDL15.1021); (e) Detail on the remaining removals of a crest visible on the proximal part of the bladelet: the crest shifted the location of the impact-point to the left, which resulted in the production of a twisted blank (PDL15.1019); (f) Marginal direct retouch of the cutting edge (PDL15.t129). 


\subsection{The osseous remains}

The osseous fragments associated with the backed points are poorly preserved and do not allow direct macroscopic identification or technological observations. Their general morphology can be described as elongated, but only flaky fragments are preservedwich are suggestive of either bone or less probably ivory. However taxonomic identification was not possible on the basis of standard macroscopic observations, and so different analyses were required to identify the material.

ZooMS collagen fingerprint analysis (Buckley et al., 2009) allowed the identification of the specimen (fig. 9) as originating from adeer (either Cervus elaphus or Dama dama). Although ZooMS cannot readily separate some deer species such as Cervus from Dama (Buckley and Kansa, 2011), the identification of Cervus elaphus is favored through known absence of Dama in this region at this time and the presence of Cervus elaphus in other layers of the site.

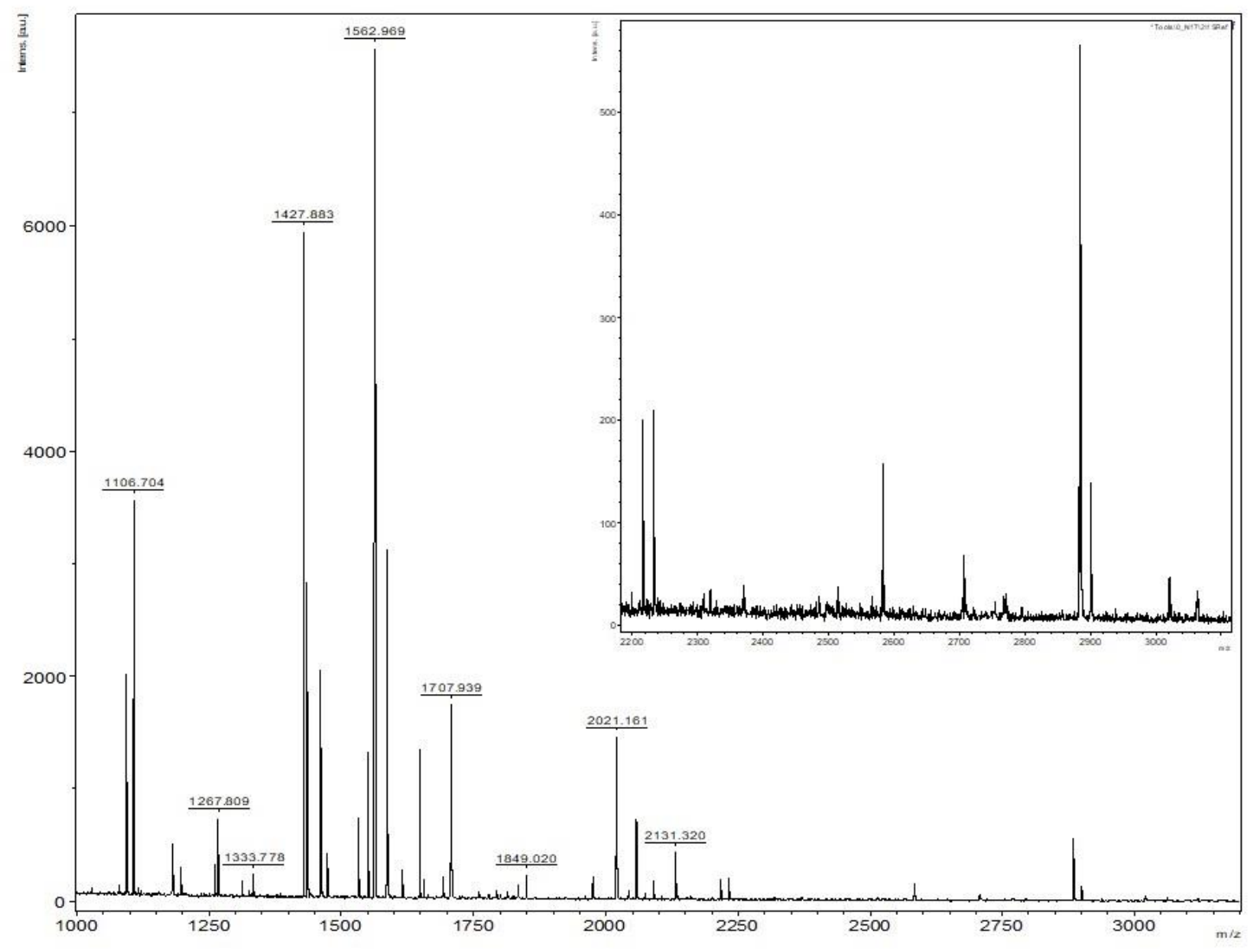

Fig. 9: Results of the ZooMS collagen fingerprint analysis, allowing to identify the osseous remains associated with the backed points as deriving from a deer.

However, the ZooMS approach does not typically differentiate between bone and antler and optical microscopy was used to this end.Generally speaking, antler should show a tubular structure that is less dense than bone (Chen et al., 2009). Our samples show a dense, aligned micro-structure that seems more indicative of bone than antler, but diagnostic features that permit to distinguish between bone and antler were obscured by the alteration of the remains (Vercoutère et al., 2011). To better highlight the structural features, different samples were submitted to SEM-EDS analysis by using a JEOL IT100 SEM equipped with a JEOL EDS (fig.10a). This procedure further highlighted the aligned and fibrous microstructure of the remains. Based on comparative archaeological reference samples, the remains proved to be most similar to bone. In addition, a micro-CT Scan was performed using a Bruker Scanjet 
(fig.10b) to examine the internal structure of the remains in comparison to the archaeological reference samples. Again, the microstructure proved most similar to bone.
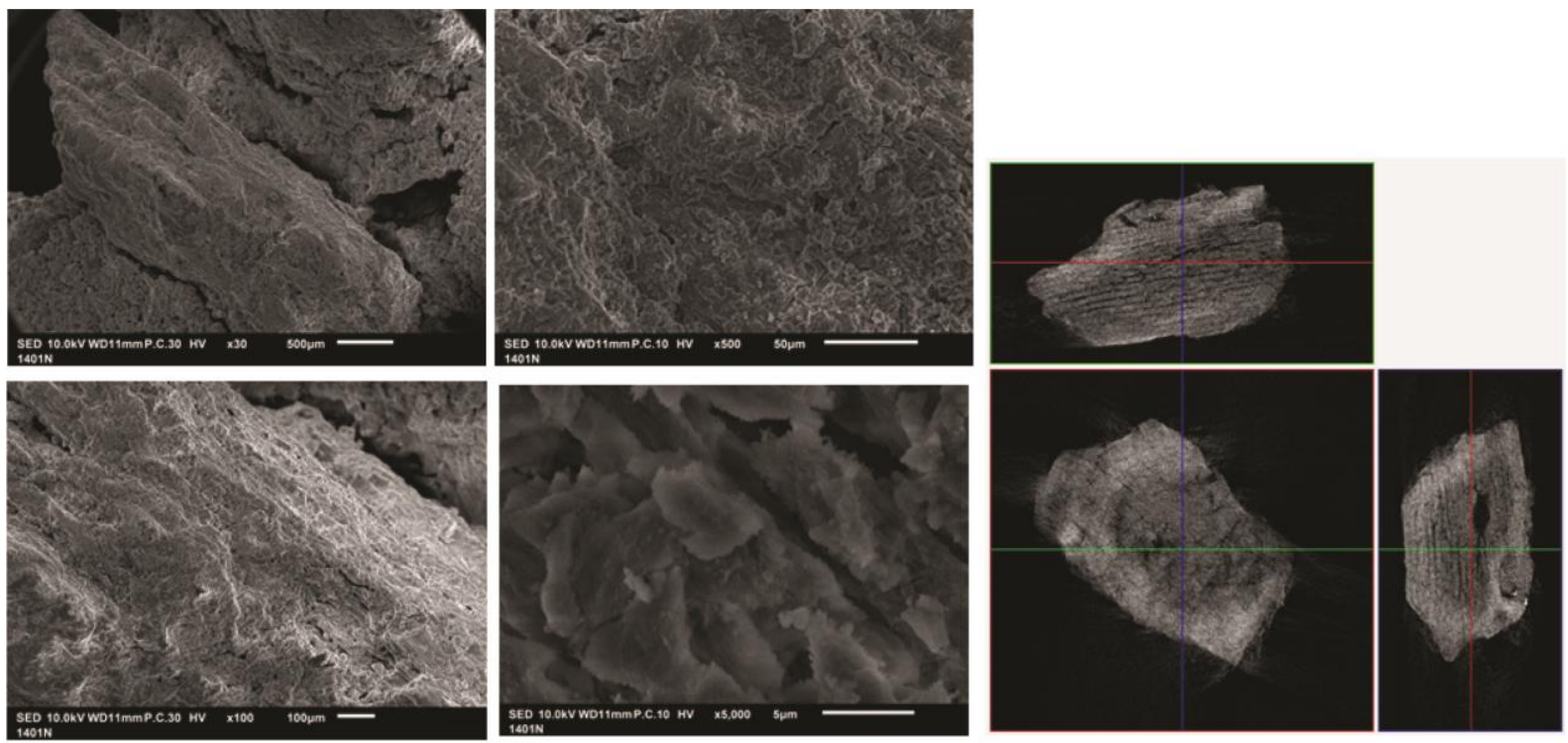

a

b

Fig. 10: (a) SEM images and (b) Micro-CT scan of the osseous fragments associated with the set of backed points.

\subsection{Design and use of the hunting weapon}

All backed points were examined for residues and wear traces (table 1). The terminology that is used is explained in the method (SI3). Some points were intensively damaged by a combination of impactrelated fractures, some in association with single spin-offs (e.g. PDL15.1014, PDL15.1021, PDL15.1401) or multiple spin-offs (e.g. PDL15.1016) (fig. 11a) and dispersed bending initiated stepterminating scars along the cutting edge (fig. 11b), while other points were less intensively damaged (e.g., PDL15.1015, PDL15.1017, PDL15.t129). Burinations (e.g., 1019) as well as microscopic linear impact traces (MLIT's) (Moss, 1983) (e.g., PDL15.1018, PDL15.1020, PDL15.1021, PDL15.1400, PDL15.1401) (fig. 11c,d) were identified. Polish formation is rare, but polish from bone contact was observed on some points (e.g., PDL15.1018, PDL15.t129) (fig. 11c,e), while other points possess a dispersed faint friction polish with some possible bone polish spots (e.g. PDL15.1401) (fig. 11f).

\begin{tabular}{|c|c|c|c|c|c|c|}
\hline \# & Summary of the use-wear analysis & $\begin{array}{l}\text { Overall } \\
\text { trace } \\
\text { intensity }\end{array}$ & $\begin{array}{l}\text { Use as } \\
\text { armature }\end{array}$ & $\begin{array}{l}\text { Use } \\
\text { as } \\
\text { barb }\end{array}$ & $\begin{array}{l}\text { Part } \\
\text { oriented } \\
\text { toward } \\
\text { apex }\end{array}$ & $\begin{array}{l}\text { Likely } \\
\text { position } \\
\text { on } \\
\text { point }\end{array}$ \\
\hline 1014 & $\begin{array}{l}\text { Proximal part: Small snap fracture on outer tip. Series } \\
\text { of bending-initiated step-terminating scars with twisted } \\
\text { profile on ventral tip. Small step- and feather- } \\
\text { terminating scars with twisted profiles on dorsal face. } \\
\text { Dispersed residues (possible blood, modern human } \\
\text { hair fragment, rootlet contamination, conidia). Distal } \\
\text { part: bending-initiated step-terminating fracture with }\end{array}$ & 3 & ++ & ++ & $\mathrm{P}$ & A \\
\hline
\end{tabular}




\begin{tabular}{|c|c|c|c|c|c|}
\hline & $\begin{array}{l}\text { associated fissure and spin-off. Striations associated } \\
\text { with edge damage on ventral edge. Possibly blood, } \\
\text { modern rootlet contamination, smeared animal tissue, } \\
\text { conidia. Edge: Bending-initiated step-terminating } \\
\text { scars, abrasion of outer edge. }\end{array}$ & & & & \\
\hline 1015 & $\begin{array}{l}\text { Proximal part: intrusive bifacial bending-initiated } \\
\text { scar with step-into-step termination on backed edge. } \\
\text { Conidia. Distal part: tiny bending-initiated step- } \\
\text { terminating fracture with tiny spin-off, sliced scars on } \\
\text { lateral edge. Smeared bone on tip. }\end{array}$ & - & & - & \\
\hline 1016 & $\begin{array}{l}\text { Proximal part: blackish residue, hyphae. Distal part: } \\
\text { large transversal fracture with twisted profile: bending- } \\
\text { initiated, snap-terminating, associated with multiple } \\
\text { superposing step-terminating spin-offs including a } \\
\text { non-detached one. Possibly blood, probable hair } \\
\text { fragment, smeared red residue, elongated large starch } \\
\text { grain (possibly from tuber). }\end{array}$ & ++ & + & $\mathrm{P}$ & A \\
\hline 1017 & $\begin{array}{l}\text { Proximal part: sliced scars on ventral face. Non- } \\
\text { intrusive bending-initiated step-terminating scarring on } \\
\text { dorsal face. Distal part: small bending-initiated step- } \\
\text { terminating scar; impact striations, residues pushed in } \\
\text { damage on distal tip. Some bone residue, brown } \\
\text { amorphous residue, orange iron oxide, elongated large } \\
\text { starch grain (possibly from tuber). }\end{array}$ & + & + & $\mathrm{P}$ & I \\
\hline 1018 & $\begin{array}{l}\text { Proximal part: Intense bifacial fracturing (oblique } \\
\text { initiation), associated with MLITs, bending-initiated } \\
\text { scars with step termination and twisted profile on edge. } \\
\text { Animal tissue, bone residue, possible blood cells in } \\
\text { various locations, dark brown / black blobs (perhaps } \\
\text { resin). Distal part: small bending-initiated step- } \\
\text { terminating fracture with strongly curved profile. } \\
\text { Small bone polish on dorsal ridge, some abrasion from } \\
\text { bone contact on ventral right edge, superficial step- } \\
\text { terminating scars. Modern human hair, possible blood. } \\
\text { Edge: linear friction features; dispersed bone-like } \\
\text { polish spots and linear features. }\end{array}$ & ++ & ++ & $\mathrm{P}$ & A \\
\hline 1019 & $\begin{array}{l}\text { Proximal part: conidia, possible blood cells. Distal } \\
\text { part: small bending-initiated feather-terminating } \\
\text { fracture with twisted profile. Thick film of red } \\
\text { substance (blood?), linear features, unidentified broken } \\
\text { hair. }\end{array}$ & - & - & $\mathrm{P}$ & - \\
\hline 1020 & $\begin{array}{l}\text { Proximal part: compression-related fracture, possible } \\
\text { bone. Distal part: bending-initiated hinge-terminating }\end{array}$ & + & + & $\mathrm{P}$ & $\mathrm{I} / \mathrm{B}$ \\
\hline
\end{tabular}




\begin{tabular}{|c|c|c|c|c|c|}
\hline & $\begin{array}{l}\text { scars associated with MLITs on dorsal face, dispersed } \\
\text { scars. Edge: sliced scars, feather- and step-terminating, } \\
\text { some alternating; associated with faint MLITs. } \\
\text { Possible bone }\end{array}$ & & & & \\
\hline 1021 & $\begin{array}{l}\text { Proximal part: step-terminating elongated removal, } \\
\text { spin-offs associated with deep crushing, faint MLITs. } \\
\text { Distal part: possible blood and bone residue within } \\
\text { scar on ventral left edge, possible resin, possible bone } \\
\text { residue. Edge: small sliced and nibbling scars, } \\
\text { superpose retouch on dorsal medial left edge. }\end{array}$ & + & + & $\mathrm{P}$ & - \\
\hline 1400 & $\begin{array}{l}\text { Proximal part: bending-initiated feather-terminating } \\
\text { fracture with twisted profile. Presence of manganese. } \\
\text { Distal part: tiny snap fracture with superficial small } \\
\text { step-terminating scar on ventral surface; short MLIT } \\
\text { on ventral tip, MLITs in BS form on dorsal tip (right), } \\
\text { bending-initiated step-terminating scar. Edge: deep } \\
\text { hinge-terminating scalar scars on dorsal left edge } \\
\text { associated with faint MLITs parallel to edge, sliced } \\
\text { step-terminating scars along right lateral edge. Possible } \\
\text { bone. }\end{array}$ & ++ & + & (D) & $A$ \\
\hline $\begin{array}{l}1401- \\
2\end{array}$ & $\begin{array}{l}\text { Proximal part: deep edge damage on ventral face } \\
\text { associated with a small step-terminating spin-off and } \\
\text { faint MLITs. Distal part: different feather- and step- } \\
\text { terminating removals initiated obliquely on dorsal tip } \\
\text { with nibbling damage on left edge. Possible bone } \\
\text { residue in scar on tip. Edge: dispersed faint friction } \\
\text { polish with possible bone spots. }\end{array}$ & ++ & ++ & $(\mathrm{P})$ & - \\
\hline $\mathrm{t} 129$ & $\begin{array}{l}\text { Proximal part: bending-initiated hinge-terminating } \\
\text { fracture, hinge is crushed. Distal part: bending- } \\
\text { initiated feather-terminating fracture. Step-terminating } \\
\text { removal associated with fracture on ventral surface. } \\
\text { Bone polish associated with fracture on ventral edge }\end{array}$ & - & $\left.\right|^{-}$ & - & - \\
\hline
\end{tabular}




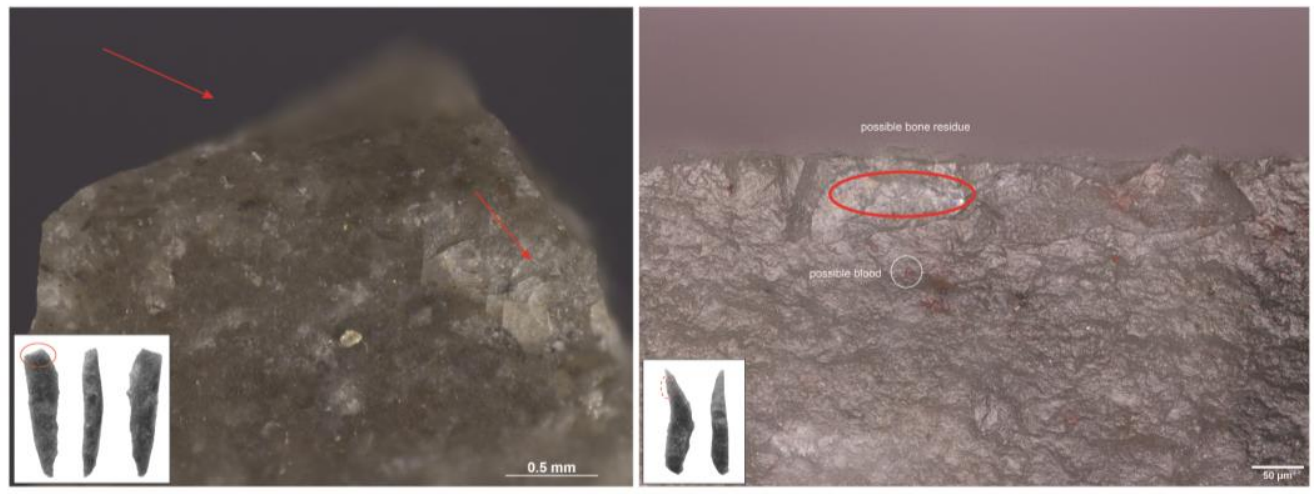

a.

b.

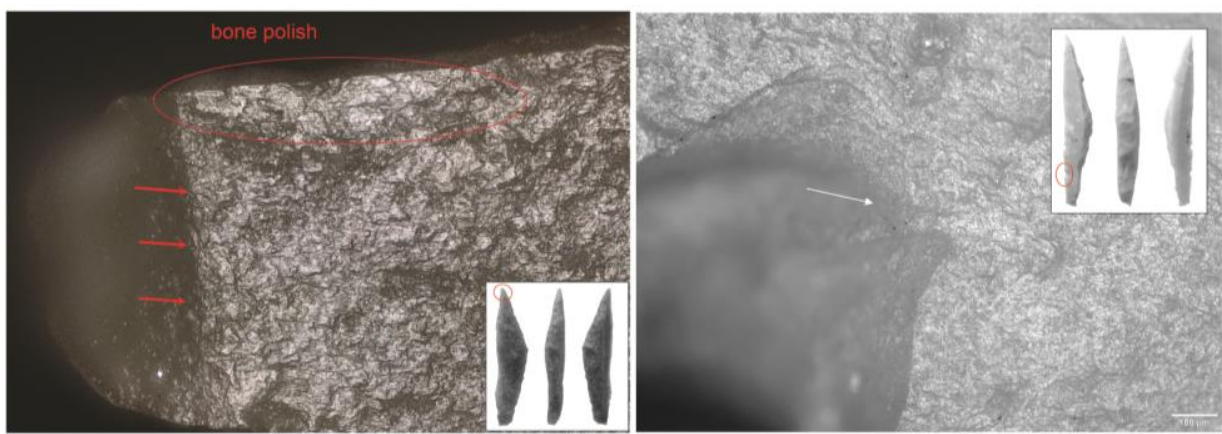

d.

C.
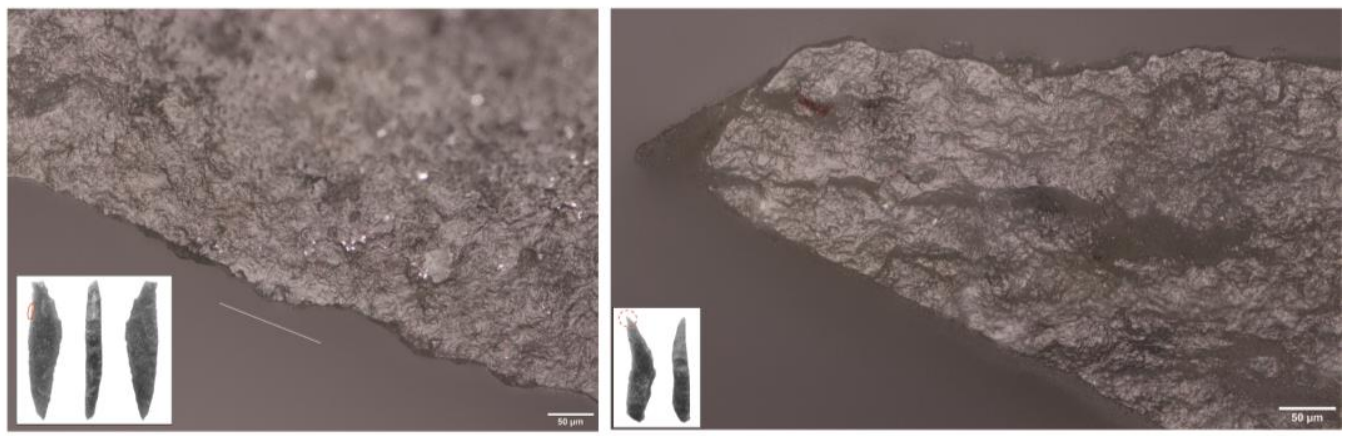

e.

f.
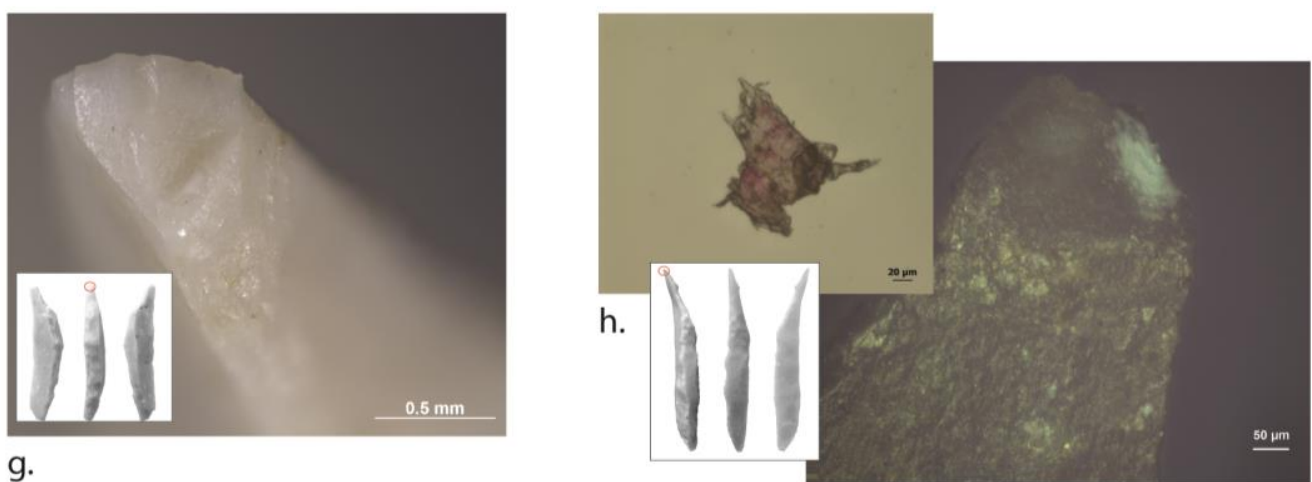

g.

Fig. 11: Use-wear analysis of the backed points. (a) Fracture with associated spin-off (x55; reflected light, point PDL15.1016). (b) Ventral distal edge, dispersed bending-initiated, step-terminating scars. Possible bone residue is circled in red (x200; reflected light, point PDL15.1021). (c) Ventral distal tip. Bone polish spot and MLITs (x200; reflected light, point PDL15.1015). (d) Ventral proximal edge. MLITs associated with edge damage (x100; reflected light, point PDL15.1400). (e) Ventral distal edge. Bone polish (x200; reflected light, point PDL15.t129). (f) Ventral distal tip. Light friction polish and possible blood residue (x200; reflected light, point PDL15.1021). (g) Distal tip. Feather- and step-terminating removals, slightly oblique, photographed end-on (x59; reflected light, point PDL15.1401-2). (h) Bone pushed into fracture on distal tip (x200, bright field, reflected light, point PDL15.1015) and bone residue extracted from distal tip and stained with Acid Fuchsin (x400, bright field, transmitted light). 
Explicit evidence for projectile usage was observed on at least 5 points, while suggestive evidence was observed on the remaining ones. The characteristics of the fractures and their organization over the points, including the occurrence of fractures that are laterally initiated and have a twisted profile on one of the extremities (fig. 11g) and/or the orientation of counter-pressure fracture phenomena (Rots, 2016), indicate the points were used as barbs. The orientation of the barbs is indicated by a few archaeological pieces. Point PDL15.1016 provides important information as the distal fracture (on the truncation) is created by a lateral force (contra an axial force) implying that the proximal extremity was oriented towards the apex of the projectile. Point PDL15.1018 presents a similar pattern, with a distal fracture that is initiated from the right edge of the tip toward the back, suggesting that the truncation was not in contact with the osseous point. In nearly all cases, oriented damage was observed on the lateral edge near the base, while damage with a twisted profile was observed near the truncation. Reliable evidence regarding the orientation was absent on two pieces only. Only one backed point (PDL15.1400) shows evidence that could indicate an inverse orientation (i.e. distal point toward the apex). This backed point is more symmetrical in morphology than the others, due to which its orientation does not significantly modify its functional parameters.

The damage on the proximal extremity of two points (PDL15.1020, PDL15.1021) witnesses a compression-related aspect that may be due to contact with another barb upon impact, which would suggest a hafting in a row (Rots, 2016). Hafting in a row is further suggested by the occurrence of intensively damaged points and less intensively damaged points. Our experimental evidence and reference material available at TraceoLab is quite compelling in terms of the fact that the first and last barbs in a series are more heavily damaged than the intermediate one(s). However, also the fact whether and how a barb detached upon impact plays a non-negligible role.

An in situ analysis of the residues allowed identifying various residues, such as bone fragments, animal tissue, possible blood, hair fragments, smeared red residue, and possible resin. Bone pressed into impact fractures was observed on several pieces (e.g., PDL15.1015, PDL15.1021). After extraction, residues were examined under transmitted light in order to reveal more of their internal structure and confirm initial identifications (fig. 11h). In addition, linear smearing of residues, indicative of a use-related origin, is abundant. To further strengthen the residue identification, some pieces were subjected to an SEM-EDS analysis (fig.12). This confirmed the organic nature of the residues that were compacted within the fractures. 

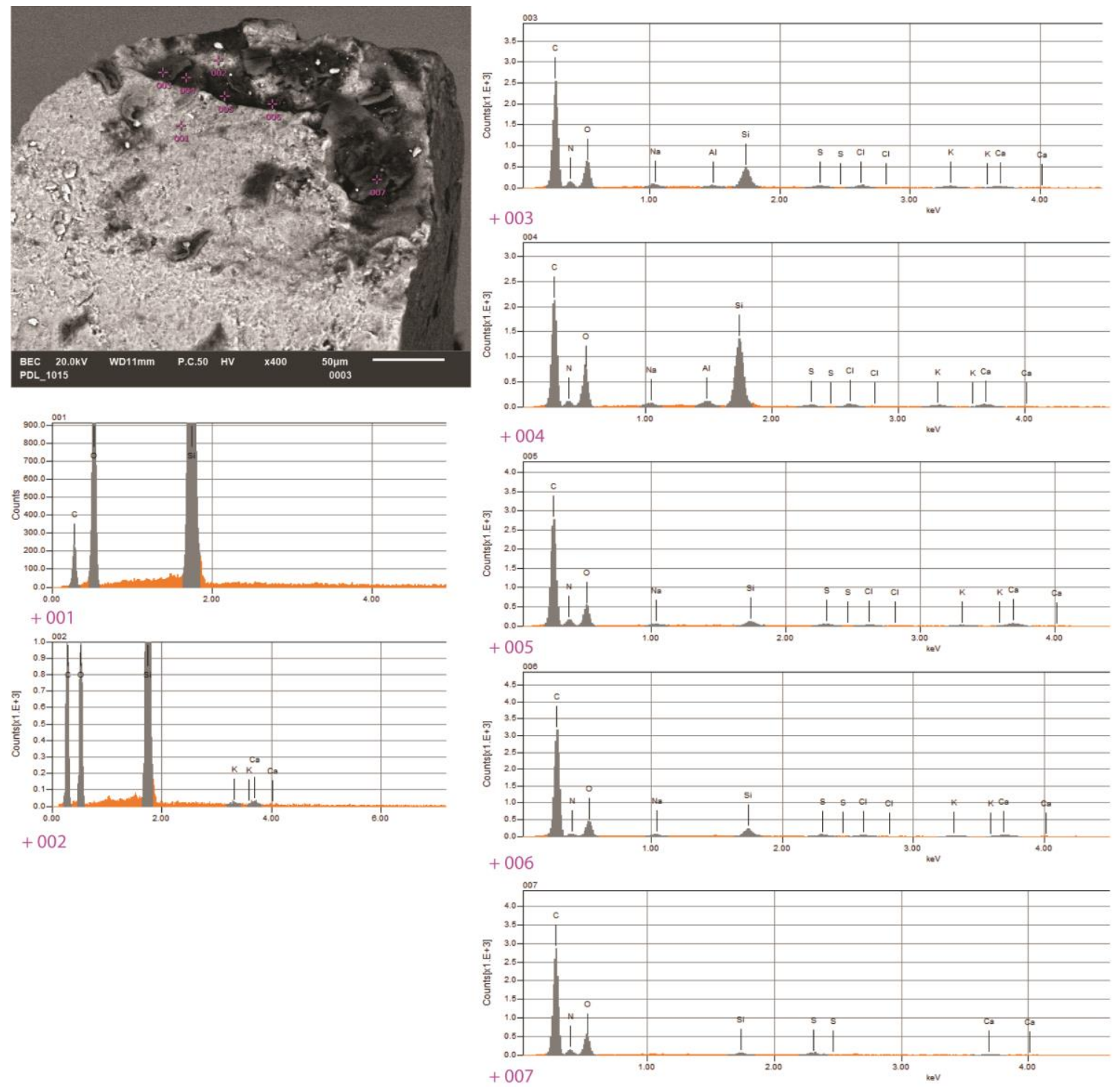

Fig.12: Results of the SEM-EDS analysis of a residue identified within the impact-related damage on the distal tip of backed point PDL15.1015. It confirms the organic nature of the residue: 001 \& 002: reference measurement on chert surface - note characteristic Si and O signal; 003-007: measurements within residue - note the high C content combined with low Si values as the residue covered the chert surface.

\subsection{Experimental testing}

To evaluate our hypotheses on the design and functioning of the weapon and to complement the usewear analysis, we conducted an exploratory experiment. The goal was to produce reference material that further supports typical damage patterns for barbs (as already identified in other experiments of our reference) (Rots, 2016) and which would permit the proposition of the most likely design for the barbed osseous point. Given the multiple potential variables involved in the case of the design and manufacture of hunting weapons (Hughes, 1978; Rots and Plisson, 2014), we limited the parameters to test. Exact copies of the backed points were reproduced. Four possible hafting designs were tested, involving differences in the distribution and orientation of the backed points on the osseous point (fig. 13). In the first design (a), we secured the truncation on the osseous point. The proximal part of the backed point was therefore oriented toward the base. For the three other designs (b, c and d) we secured the back on the osseous point with the proximal part of the backed point oriented toward the apex. Barbs were placed in two rows of three barbs (design b); three rows of three barbs (design c) or randomly around the osseous point (design d). 


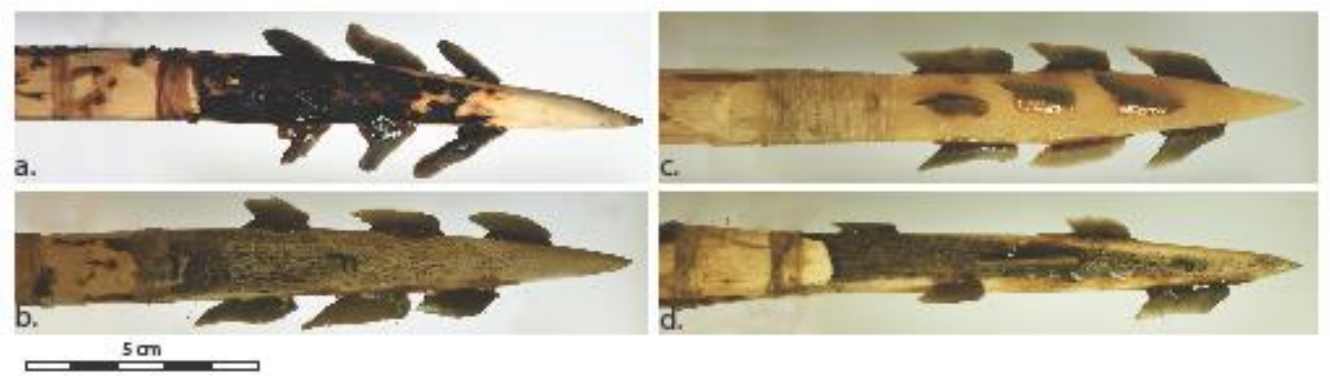

Fig. 13: Design ( $a, b, c$ and $d$ ) of the experimental hafted barbed points.

Two natural glues (a resin-based mixture and protein glue) were tested. To guarantee comparability and eliminate variation that may result from specific conditions at the moment of impact, each glue type was used to secure one row of barbs on a single osseous point for design types (a) and (b). Only resin-based glue was used for design type (c) and (d) given the absence of symmetry in these designs. One artificial target was used consisting of a real animal skeleton (pony) incorporated in a ballistic gel casing that is covered by a stretched pony hide (for details on the target configuration see method and Coppe and Rots, 2017). Finally, two projecting modes were tested, the spear-thrower and the bow following on-going debate regarding projecting modes of hunting weapons during the Upper Paleolithic (Coppe and Rots, 2017). Both options share the fact that they are projected from a distance; this choice does not exclude the possibility that the weapon was thrust or thrown by hand. The spearthrower allows less control over the propulsion than the bow, which implies that there is a higher risk of not successfully hitting the target. Therefore, the test included twice the number of spearheads in comparison to arrowheads, in order to guarantee that the experiment would produce a sufficient number of spearheads that successfully hit the target in comparison to the arrowheads for which a successful hit was more certain. Detailed results are provided in the supplementary material (S8); only a summary is presented in table 2 .

\begin{tabular}{|c|c|c|c|c|c|c|c|}
\hline \multirow{2}{*}{ Design } & \multirow{2}{*}{ Points } & \multirow{2}{*}{ Barb } & \multirow{2}{*}{$\begin{array}{l}\text { No } \\
\text { relevant } \\
\text { damage }\end{array}$} & \multicolumn{3}{|c|}{ Relevant damage } & \multirow[b]{2}{*}{ Main wear traces identified } \\
\hline & & & & Proximal & Distal & \begin{tabular}{|l} 
Cutting \\
edge
\end{tabular} & \\
\hline $\mathrm{a}$ & 4 & 21 & 10 & 1 & 4 & 12 & $\begin{array}{l}\text { Proximal part: in a single case, sliced } \\
\text { into scalar fracture. Distal part: } \\
\text { fractures caused by axial pressure. } \\
\text { Cutting edge: Dispersed uni- or } \\
\text { bifacial scars, bending initiation, } \\
\text { feather and step termination. Oriented } \\
\text { toward the proximal part. A transverse } \\
\text { fracture. }\end{array}$ \\
\hline b & 4 & 21 & 12 & 3 & 1 & 3 & $\begin{array}{l}\text { Proximal part: fractures related with } \\
\text { an axial pressure. Distal part: In a } \\
\text { single case, sliced into scalar fracture. } \\
\text { Cutting edge: Dispersed unifacial } \\
\text { bending-initiated, feather- or step- } \\
\text { terminating scars oriented toward the } \\
\text { distal end. Two transverse fractures, }\end{array}$ \\
\hline
\end{tabular}




\begin{tabular}{|c|c|c|c|c|c|c|c|}
\hline & & & & & & & one associated with a spin-off. \\
\hline $\mathrm{c}$ & 2 & 16 & 13 & 3 & 2 & 3 & $\begin{array}{l}\text { Proximal part: fractures related with } \\
\text { an axial pressure. Distal part: In a } \\
\text { single case, long twisted burination } \\
\text { along the cutting edge initiated on the } \\
\text { truncation. Probably related with } \\
\text { counter-pressure. Cutting edge: } \\
\text { Dispersed unifacial bending-initiated, } \\
\text { feather- or step-terminating scars } \\
\text { oriented toward the distal end. Sliced } \\
\text { scars on the distal part of the cutting } \\
\text { edge. Two transverse fractures, one } \\
\text { associated with a spin-off. }\end{array}$ \\
\hline $\mathrm{d}$ & 2 & 10 & 9 & 0 & 2 & 1 & $\begin{array}{l}\text { Distal part: In a single case, bending- } \\
\text { initiated step-terminating fracture with } \\
\text { spin-off. Cutting edge: Dispersed } \\
\text { unifacial bending-initiated, feather- or } \\
\text { step-terminating scars oriented toward } \\
\text { the distal end. }\end{array}$ \\
\hline
\end{tabular}

Table 2: Results of the experiment with documented wear patterns

We prepared 16 points, all of which were used for a single shot, four missed the target (one for each design), leaving a total of 12 composite points. In total, 10 barbs were lost upon impact, while 83 barbs were recovered in total. For each hit, at least one barb de-hafted. A relatively high number of barbs did not show relevant traces $(n=41)$, while the 42 remaining ones showed at least one or several fractures.

The barbs of the "design (a)" point have very specific impact traces. Scars along the cutting edge occur frequently (fig. 14a,d,e). The distal point (i.e. the truncation) shows damage related with an axial force (fig. 14b,c), while the proximal part often shows scars related to a counter-pressure (fig. 14f). A single fracture identified in the proximal part of one backed point indicates a twisted force.
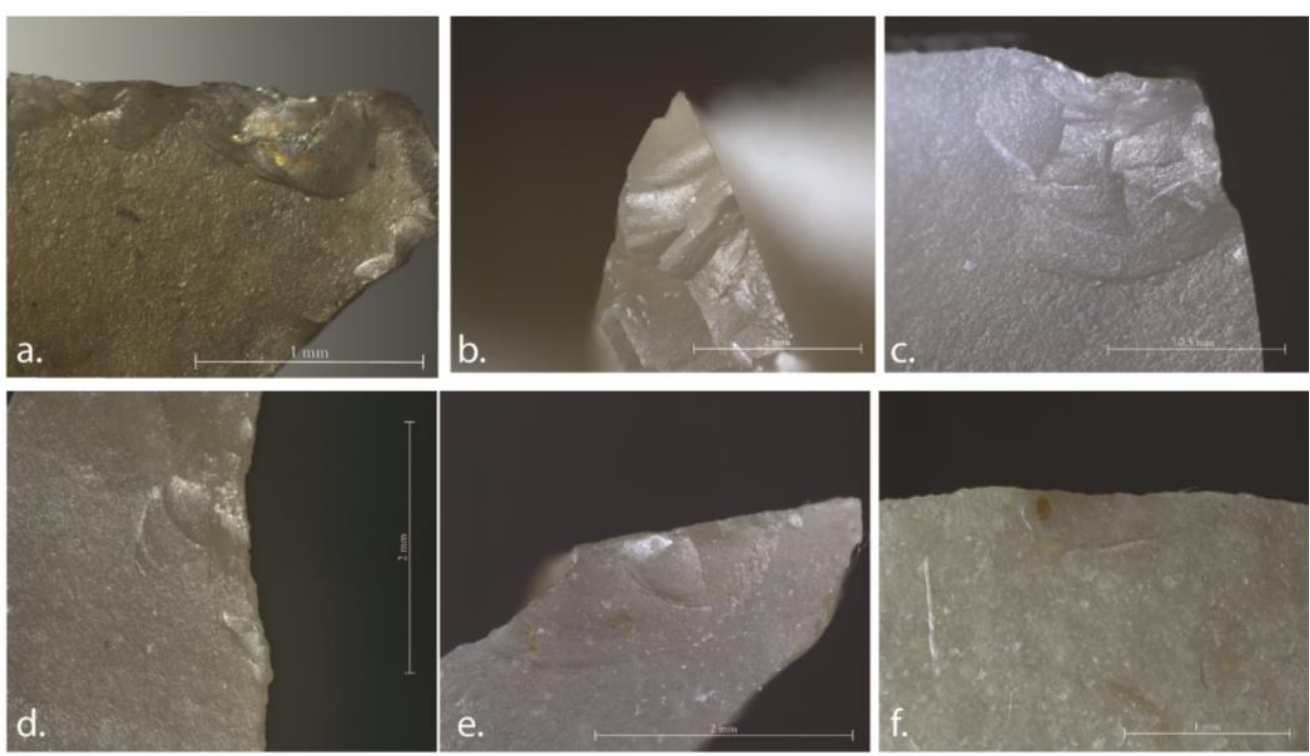
Fig. 14: Impact damage on barbs of the "design (a)" points. (a) Distal right ventral edge: scarring with bending initiation, feather and step termination, oriented obliquely toward the proximal extremity $(89 N 06, x 75)$. (b) Distal tip: bending-initiated fracture with hinge termination $(89 N 104, x 42.5)$. (c) Dorsal distal tip: scars with cone initiation and step termination (89N104, x75). (d) Ventral distal right edge: lateral scarring, predominantly hinge-terminating (89N101, $x 75)$. (e) Ventral distal right edge: step-terminating scars $(89 G 72, x 64)$. (f) Dorsal proximal right edge: large bending-initiated and stepterminating scar (89G72, x58).

The three other point designs show comparable damage patterns. The proximal point frequently has damage caused by an axial force, consisting of large scars (fig. 15a) and/or transverse fractures associated with a spin-off (fig. 15b). Scars occur frequently on both faces of the cutting edges (fig. $15 \mathrm{c}, \mathrm{d}, \mathrm{e})$. The distal point (i.e. the truncation) frequently shows a twisted fracture that is initiated from the cutting edge (fig. 15f).
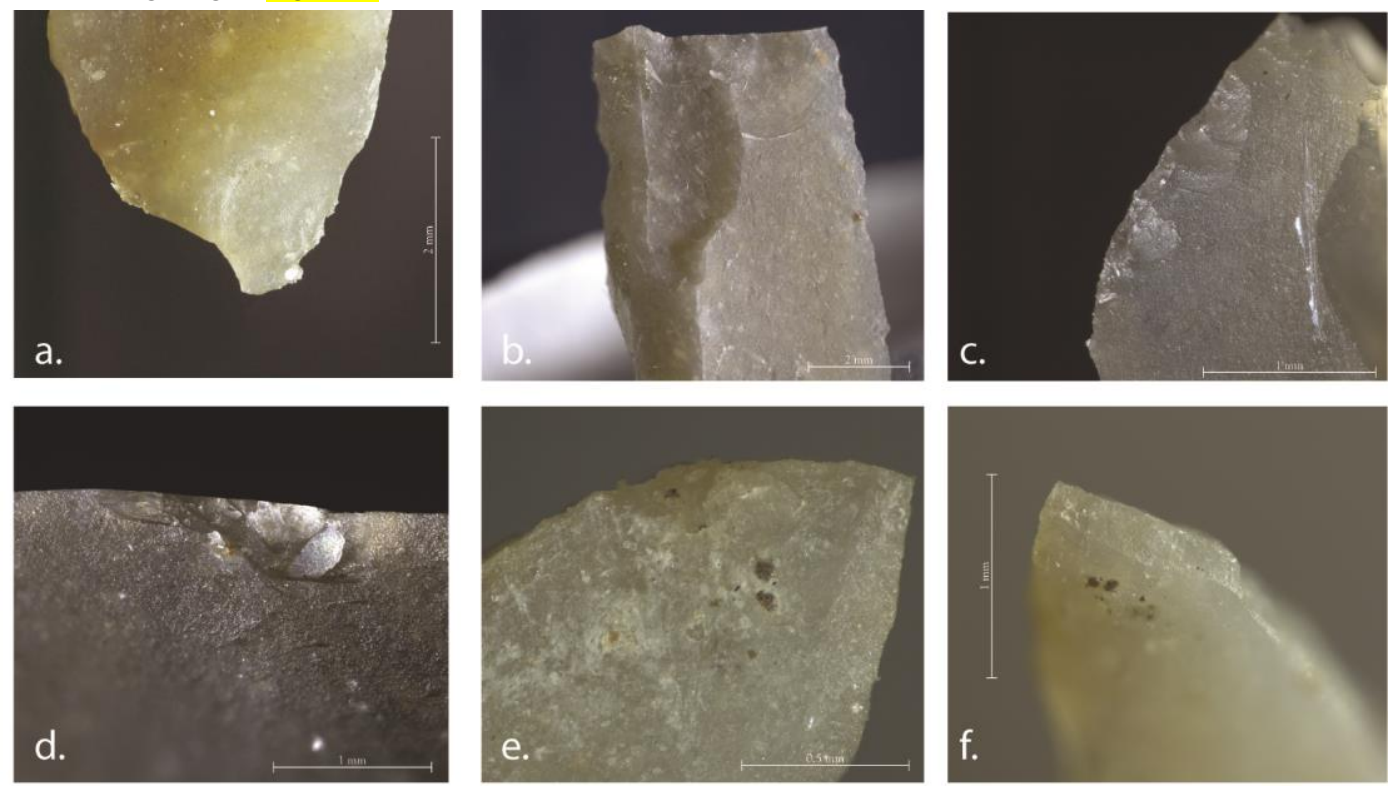

Fig. 15: Impact damage on barbs of the point "design (b)". (a) Ventral proximal tip: scar with bending initiation, feather termination and curved profile (89E10, x24.5). (b) Spin-off initiated from a proximal transverse fracture caused by impact (89F14, x24.5). (c) Dorsal proximal left edge: bending-initiated and feather-terminating scars (89F89, x24.5). (d) Ventral mesial left edge: concentration of superposing step-terminating scars (89E10, x24.5). (e) Distal ventral tip: bending-initiated and feather-terminating scars $(89 A 26, x 160)$. (f) Distal tip: burination initiated on the cutting edge, twisted profile (89A26, x117).

Our experimental results are consistent with previous studies (Chesnaux, 2014; Yaroshevich et al., 2013) and support the use-wear interpretations proposed for the archaeological lithic backed points. The use-wear traces on barbs that are secured on an osseous point with their proximal point facing the apex are recurring and consist of two principal areas of trace production: one near the apex of the lithic point consisting of oriented and often deep uni- or bifacial scarring and another one near the truncation characterized by a strong bending force resulting in scars with twisted profiles occurring potentially on both the cutting edge and the truncation. The organization of these two damage concentrations proves to be indicative for the orientation of the barb on the putative bone point. Indeed, the organization of the microscopic use-wear traces for design (a) is opposite to the one observed on the archaeological pieces. The experimental results therefore confirm that the orientation of the barbs can be reliably based on the damage pattern and that the archaeological barbs were hafted with their truncation toward the base of the projectile.

\section{Identification of a composite barbed point}

Field data and laboratory analyses converge to hypothesize that the 11 lithic armatures found together with the remains of an osseous element were part of a single composite barbed point. Use-wear 
analysis demonstrates that the backed points were used as barbs on a projectile. Particularly striking is their great homogeneity in all categories: petrographically, technologically and typologically.

Demonstrating that the osseous element was initially a bone point is hindered by the important alteration of the remains not permitting a technical and morphological description. Several lines of evidence support such an interpretation. The association with the armatures is remarkable and it has to be noted that the osseous remains originate from a red deer bone, which contrasts with all other bones from the excavated area that were all identified as being horse remains. In addition, spatial and micromorphological analysis both support the limited disturbance of the archaeological layer and the good preservation of the initial repartition of the artefacts. Considering these facts, we consider that the distribution of the backed points is representative of the position and organization of the remains before burial. The four longest armatures were symmetrically distributed on both sides of the deer osseous remains, while two barbs were found directly in contact with the putative bone point. Finally, the distribution of the backed points along the elongated osseous element, together with their functional orientation as inferred from use-wear analysis (fig. 16a), allows identifying a composite barbed point that decomposed in-situ.

While an exact reconstruction of the composite point remains hypothetic, a likely design may be proposed on the basis of our analytical results and existing knowledge on European Upper Paleolithic projectile points. All currently known composite points, such as osseous barbed points, have one or two opposing rows of lithic insets. In our case, considering the high number of barbs and their specific distribution around the bone remains, we concur that the evidence best supports the hypothesis of a design with two rows of barbs on the putative bone point (fig. 16b), but other designs cannot be firmly excluded (e.g., three rows or dispersed positions of the barbs). The length of the complete projectile point cannot be confidently established given the preservation state of the osseous remains and the length of these remains $(\mathrm{L}=11,6 \mathrm{~cm})$ therefore only provides a minimal estimate. It is presently impossible to propose a propulsion mode or to infer whether or not the weapon was projected from a distance based on the available evidence. 


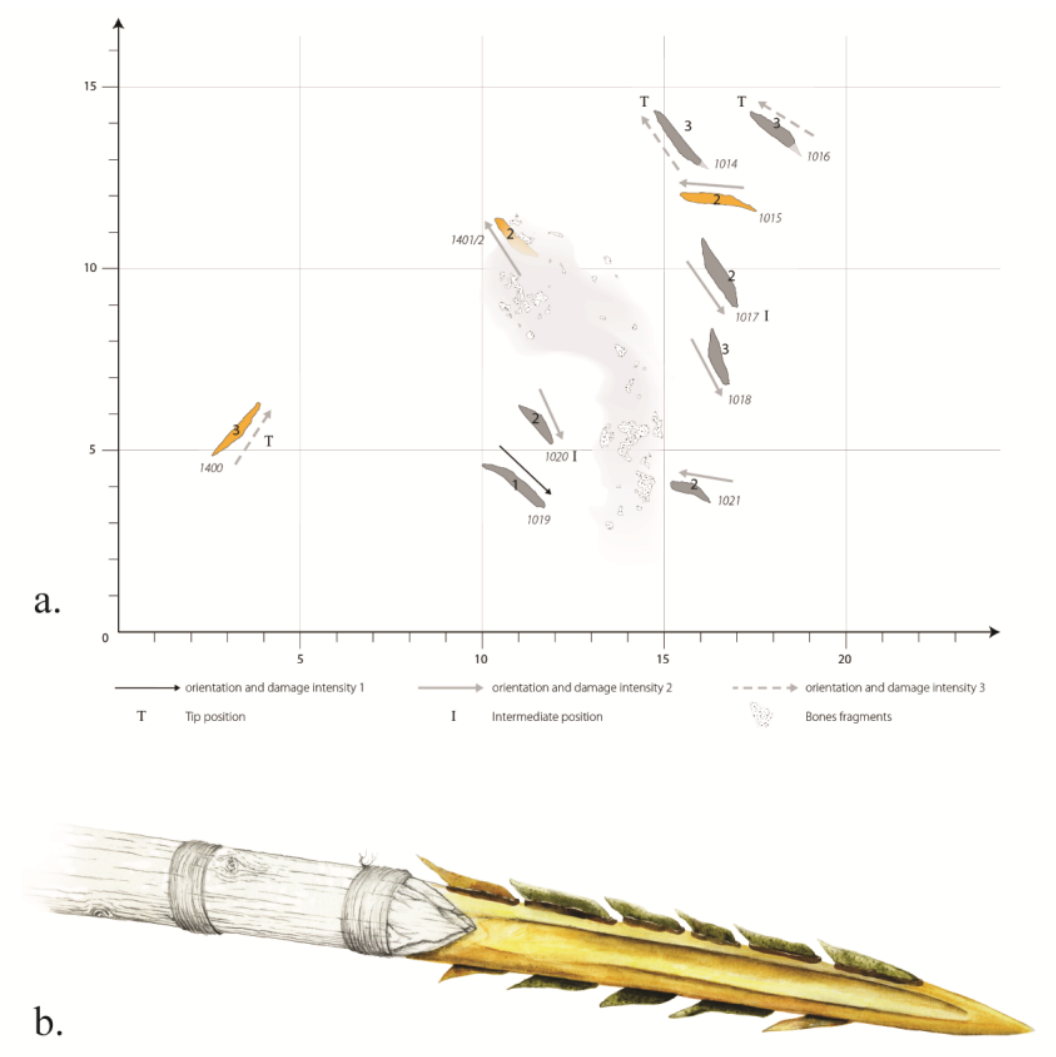

Fig. 16: (a) spatial distribution of the lithic backed points with their use-wear evidence and (b) hypothesized design of the Gravettian composite point of Les Prés de Laure (the proposed reconstruction is based on spatial, functional and experimental data). Colors indicate the raw material of the recovered archaeological barbs: yellow for those made out of tertiary chert, black for those made out of the Valanginian chert.

\section{Discussion}

The recent discovery and excavation of the open-air site Les Prés de Laure offers new insights into the way Gravettian groups organized their technologies and how they occupied the Liguro-Provençal arc at ca. 25-23.5 ka cal BP. Thanks to rapid burial by fine alluvial deposits, it was possible to expose a $9 \mathrm{~m}^{2}$ archaeological surface in a well-preserved context with a low density of organic and inorganic artefacts, documenting human occupations oriented towards the exploitation of horses. Of particular importance is the discovery of 11 lithic armatures associated with osseous fragments interpreted as a composite barbed point.

The two radiocarbon dates, together with the results from the micromorphological and technoeconomic analyses, suggest that the archaeological unit under study represents several occupation events. Further excavation, spatial analyses and new radiocarbon dates will have to secure the exact chronology of the techno-economic events found at Les Prés de Laure. With regard to the dating of the composite barbed point, we presently favor the date of $23.5 \mathrm{ka}$ cal BP considering that the dated specimen originates from the same depth and excavation square as the weapon.

The find in combination with the analytical results have several implications for our knowledge about Upper Paleolithic hunting weaponry. First of all, it pushes back the date of barbed composite projectile points to ca. $23.5 \mathrm{ka}$ cal. BP. Such points were previously only known to have existed in the Mesolithic period. Lithic barbs had already been identified for the Upper Paleolithic period 
(Yaroshevich et al., 2013), but without the factual demonstration that they were hafted on an osseous point in a composite projectile arrangement. However, other evidence from the post-LGM period does support the existence of (1) composite points with backed bladelets as cutting edges (Pétillon et al., 2011) and (2) barbed osseous (not composite) points (Pétillon, 2016). Our study thus confirms what had been assumed up to now: barbed composite projectile points predate the Mesolithic and are anchored in the Upper Paleolithic. Other similar evidence for the use of barbed composite points may be revealed in the future. Indeed, the lamelles scalènes of the middle Magdalenian (Langlais, 2004) show a remarkable morphological convergence with the barbs identified here and appear highly relevant to be considered in this perspective.

Another striking element is the nature of the possible osseous point itself, which would be manufactured out of red deer bone, while most of other Upper Paleolithic examples are manufactured out of reindeer antler. Nevertheless, the use of bone is consistent with evidence from Eurasia. For example, points made of bone and antler are present in the archeological record of the bison kill and camp sites of Amvrosievka (ca. 23-21 ka cal. BP) in Eastern Ukraine, some of which present a single longitudinal groove (Julien and Krotova, 2008; Krotova and Belan, 1993). These osseous points were interpreted as possible bases of composite weapons with laterally hafted backed microliths, even though no direct evidence for such an association was recovered (Boriskovskji, 1953; Nuzhnyi, 1990). Besides, deer bone projectile points (not antler points) are typical raw material in some European Mesolithic contexts, and were support for the insert of microliths (David, 2006). Additional raw materials suitable for manufacturing weapon points is also demonstrated by other evidence from Eurasian Palaeolithic contexts, such as the ones made out of mammoth ivory or even rhinoceros horn (Nikolskiy and Pitulko, 2013).

Finally, the fact that also two apical fragments of microgravette points were found in the same SU is interesting as their wear pattern appears to diverge from the barbs associated with the putative bone point. Evidence on the apical fragments is limited, but the damage and fractures indeed appear to suggest an axial impact, which would imply that they were used as tips and not as barbs. This is consistent with previous propositions (Nuzhnyj, 2007; Soriano, 1998). Though this hypothesis needs to be further tested with a larger sample and further discussed in terms of its functional association, our preliminary data suggest that stone-tipped weapons and composite barbed weapons coexisted during the Gravettian occupations at Les Prés de Laure. Various explanations could be proposed for this purported coexistence, such as the combination of close-range and long-range weapons, the pursuit of different types of prey and variation in hunting strategies.

Evidence for the use of hunting weapons increases throughout the Upper Pleistocene, but the archaeological record still remains very incomplete, hampering the construction of solid models on the design of hunting weapons and their functional and cultural parameters. Hunting weapons play a key role in the evolution of hominin subsistence and in the history of techniques and the discovery made at the site of Les Prés de Laure contributes significant new data to their understanding. The find also emphasizes the importance of integrating osseous and lithic data as a precondition for comprehending prehistoric hunting weapons. The discovery triggers reflection on the design and evolution of prehistoric weaponry and sheds new light on how to interpret the occurrence and variability of microlithic backed tools.

\section{Acknowledgments}

The authors wish to acknowledge the support from the society JEOL (in particular the assistance of C. van Lint) for the SEM-EDS analysis and from P.-J. Stiers (Clinical and Experimental Endocrinology, University of Leuven) for the micro-CT-Scan. Their help was greatly appreciated. We thank the 
Chercheurs de la Wallonie for their help with stone tool production. Archaeological reference material for bone and antler was kindly made available to us by Wim Van Neer and Bea De Cupere (Belgian Royal Institute for Natural Sciences). We thank William Archer for his useful comments on earlier drafts of this paper as well as the reviewers whose remarks helped us to strengthen the paper.

\section{References}

Abramova, Z., 1984. Upper Palaeolithic of Asian part of USSR, in: Boriskovski, P.J. (Ed.), Paleolithic of the USSR. Nauka, Moskva, pp. 302-348.

Abramova, Z., 1982. Zur Jagd im Jungpalaolithikum: nach beispielen des jungpalaolitischen fundplatzes Kokorevo I in Sibiren. Archäologisches Korrespondenblatt 12, 1-9.

Allain, J., Descouts, J., 1957. À propos d'une baguette à rainure armée de silex découverte dans le Magdalénien de Saint-Marcel. L'Anthropologie 61, 503-51.

Bárta, J., 1989. Hunting of brown bears in the Mesolithic: evidence from the Medvedia Cave near Ružín in Slovakia, in: Bonsall, C. (Ed.), The Mesolithic in Europe. John Donald Publishers, Edinburgh, pp. 456-460.

Barton, R.N., Bergman, C.A., 1982. Hunters at Hengistbury: some evidence from experimental archaeology. World Archaeology 14, 237-248.

Boëda, E., Geneste, J.-M., Griggo, C., Mercier, N., Muhesen, S., Reyss, J.-L., Taha, A., Valladas, H., 1999. A Levallois point embedded in the vertebra of a wild ass (Equus africanus): hafting, projectiles and Mousterian hunting weapons. Antiquity 73, 394-402.

Bon, F., 2005. Little big tool. Enquête autour du succès de la lamelle, in: Le Brun-Ricalens, F., Bordes, J.-G., Bon, F. (Eds.), Productions Lamellaires Attribuées à l'Aurignacien : Chaînes Opératoires et Perspectives Technoculturelles XIVe Congrès de 1'UISPP, Liège 2-8 Septembre 2001, ArchéoLogiques. MNHA, Luxembourg, pp. 479-484.

Boriskovsky P. I., 1953. Paleolithic in Ukraine, Moscow-Leningrad: Materials and research in archaeology, $40 \mathrm{p}$.

Buckley, M., Collins, M., Thomas-Oates, Ja., Wilson, L., 2009. Species identification by analysis of bone collagen using matrix-assisted laser desorption/ionisation time-of-flight mass spectrometry. Rapid Communication in Mass Spectrometry 23, 3843-3854. https://doi.org/10.1002/rcm.4316

Buckley, M., Kansa, S.W., 2011. Collagen fingerprinting of archaeological bone and teeth remains from Domuztepe, South Eastern Turkey. Archaeological and Anthropological Sciences 3, 271-280.

Chen, P.-Y., Stokes, A.G., McKittrick, J., 2009. Comparison of the structure and mechanical properties of bovine femur bone and antler of the North American elk (Cervus elaphus canadensis). Acta Biomaterialia 5, 693-706.

Chesnaux, L., 2014. Réflexions sur le microlithisme en France au cours du Premier Mésolithique (XèVIIIè millénaire av. J.C.). Approche technologique, expérimentale et fonctionnelle. Université Paris 1 Panthéon Sorbonne, Paris.

Chesnaux, L., 2008. Des microlithes sauveterriens, témoins de l'armement des derniers chasseurscueilleurs dans les Alpes du Nord., in: Pétillon, J.-M., Dias-Meirinho, M.-H., Cattelain, P., Honegger, M., Normand, C., Valdeyron, N. (Eds.), Recherches Sur Les Armatures de Projectiles Du Paléolithique Supérieur Au Néolithique, P@lethnologie, 1. Presented at the colloque C83, XVe congrès de l'UISPP, 4-9 septembre 2006, Lisbonne, pp. 139-153.

Christensen, M., Valentin, B., 2004. Armatures de projectiles et outils, in: Pigeot, N. (Ed.), Les Derniers Magdaléniens d'Étiolles. Perspectives Culturelles et Paléohistoriques (l'unité d'habitation Q31, Supplément à Gallia Préhistoire. CNRS éditions, Paris, pp. 107-160.

Cnuts, D., Rots, V., 2017. Extracting residues from stone tools for optical analysis: towards an experiment-based protocol. Archaeological and Anthropological Sciences. https://doi.org/10.1007/s12520-017-0484-7

Coppe, J., Rots, V., 2017. Focus on the target. The importance of a transparent fracture terminology for understanding projectile points and projecting modes. Journal of Archaeological Science: Reports 12, 109-123. https://doi.org/10.1016/j.jasrep.2017.01.010 
Costa, S., Davtian, G., Purdue, L., Tomasso, A., Porraz, G., 2015. Cartographie géomorphologique en contexte archéologique dans la moyenne vallée du Jabron (Var, France). Géomatique Expert 107, 20-31.

Crombé, P., Perdaen, Y., Sergant, J., Caspar, J.-P., 2001. Wear analysis on early Mesolithic microliths from the Verrebroek site, East Flanders, Belgium. Journal of Field Archaeology 28, 253-269.

David, E., 2006. Contributions of the Bone and Antler Industry for Characterizing the Early Mesolithic in Europe, in: After the Ice Age Settlements, Subsistence and Social Development in the Mesolithic of Central Europe, Materialhefte Zur Archäologie. pp. 135-145.

Dolukhanov, P., 2008. The Mesolithic of European Russia, Belarus and the Ukraine, in: Bailey, G., Spikin, P. (Eds.), . Cambridge University Press, pp. 280-301.

Elston, R.G., Kuhn, S.L., 2002. Thinking Small: Global Perspectives on Microlithization, Archeological Papers of the American Anthropological Association. Arlington.

Fernandez, P., Legendre, S., 2003. Mortality curves for horses from the Middle Palaeolithic site of Bau de l'Aubesier (Vaucluse, France): methodological, palaeo-ethnological, and palaeoecological approaches. Journal of Archaeological Science 30, 1577-1598. https://doi.org/10.1016/s0305-4403(03)00054-2

Finlayson, B., Mithen, S., 1997. The Microwear and Morphology of Microliths from Gleann Mor, in: Knecht, H. (Ed.), Projectile Technology, Interdisciplinary Contributions to Archaeology. New York Plenum Press, New York, pp. 107-129.

Fischer, A., 1989. Hunting with Flint-Tipped Arrows: results and experiences from practical experiments, in: Bonsall, C. (Ed.), The Mesolithic in Europe. John Donald, Edinburgh, pp. 29-39.

Graf, K.E., 2008. Is It Really That Old? Dating the Siberian Upper Paleolithic Site of Afontova Gora2. Current research in the Pleistocene 25, 45-47.

Gvosdover, M.D., 1952. A Composite Point from the Paleolithic Site of Talitskij. Scientific Notes of Moscow State University 158, 207-210.

Hayes, E.H., Cnuts, D., Lepers, C., Rots, V., 2017. Learning from blind tests: Determining the function of experimental grinding stones through use-wear and residue analysis. Journal of Archaeological Science 11, 245-260.

Henshilwood, C.S., D’Errico, F., Marean, C.W., Milo, C.W., Yates, R., 2001. An early bone tool industry from the Middle Stone Age at Blombos Cave, South Africa: implications for the origins of modern human behaviour, symbolism and language. Journal of Human Evolution 41, 631-678.

Hoppe, K.A., Stover, S.M., Pascoe, J.R., Amundson, R., 2004. Tooth enamel biomineralization in extant horses: implications for isotopic microsampling. Palaeogeography, Palaeoclimatology, Palaeoecology 206, 355-365.

Houmard, C., 2003. Réflexions sur les têtes de projectiles rainurées d'après l'étude du site de La Garenne (Indre). Préhistoire Anthropologie Méditerranéenne 12, 165-172.

Houmard, C., Jacquot, E., 2009. Des têtes de projectile composites à "La Garenne," in: Despriée, J., Tymula, S., Rigaud, A. (Eds.), Données Récentes Sur Le Magdalénien de "La Garenne" (Saint-Marcel, Indre) et La Place Du Magdalénien "à Navettes” En Europe, Archéologie Du Val de Creuse En Berry, Bulletin de l'ASSAAM. Argenton-sur-Creuse, pp. 137-150.

Hughes, R.E., 1978. Aspects of prehistoric Wiyot exchange and social ranking. Journal of California Anthropology 5, 53-66.

Julien, M.-A., Krotova, A., 2008. Preliminary results of a new zooarchaeological study at Amvrosievka. Archaeological Almanac 19, 189-200.

Knecht, H., 1997. The history and development of projectile technology research, in: Knecht, H. (Ed.), Projectile Technology, Interdisciplinary Contributions to Archaeology. Plenum press, New York, pp. 3-35.

Kozlowski, S.K., 2009. Thinking Mesolithic. Oxbow Books.

Krotova, A., Belan, N., 1993. Amvrosievka: A unique Upper Palaeolithic site in Eastern Europe, in: Soffer, O., Praslov, N. (Eds.), From Kostenki to Clovis. Upper Palaeolithic - Paleo-Indian Adaptations. Plenum Press, New-York and London, pp. 125-142.

Langlais, M., 2004. Les lamelles à dos magdaléniennes du Crès (Béziers, Hérault) : variabilité des modalités opératoires et stabilité typométrique. Bulletin Préhistoire du Sud-Ouest 11, 23-38. 
Larsson, L., Sjöström, A., 2010. Early Mesolithic flint-tipped arrows from Sweden. Antiquity 85.

Leroi-Gourhan, A., 1983. Une tête de sagaie à armature de lamelles de silex à Pincevent (Seine-etMarne). Bulletin de la Société préhistorique française 80, 154-156.

Matheson, C.D., Veall, M.A., 2014. Presumptive blood test using Hemastix ${ }^{\circledR}$ with EDTA in archaeology. Journal of Archaeological Science 41, 230-241.

McBrearty, S., Brooks, A.S., 2000. The revolution that wasn't: a new interpretation of the origin of modern human behavior. Journal of Human Evolution 39, 453-563. https://doi.org/10.1006/jhev.2000.0435

McDonald, J.J., Donlon, D., Field, J.H., Fullagar, R.L.K., Coltrain, J.B., Mitchell, P., Rawson, M., 2007. The first archaeological evidence for death by spearing in Australia. Antiquity 81, 877885. https://doi.org/10.1017/S0003598X00095971

Moss, G., 1983. The Functional Analysis of Flint Implements: Pincevent and Pont D'Ambon: Two Case Studies from the French Final Palaeolithic, British Archaeological Reports International Series. Oxford.

Naudinot, N., Tomasso, A., Messager, E., Finsinger, W., Ruffaldi, P., Langlais, M., 2017. Between Atlantic and Mediterranean: Changes in technology during the Late Glacial in Western Europe and the climate hypothesis. Quaternary International 428, 33-49. https://doi.org/10.1016/j.quaint.2016.01.056

Nelson, M.C., 1997. Projectile Points Form, Function, and Design, in: Knecht, H. (Ed.), Projectile Technology, Interdisciplinary Contributions to Archaeology. New York Plenum Press, New York, pp. 371-384.

Nikolskiy, P., Pitulko, V., 2013. Evidence from the Yana Palaeolithic site, Arctic Siberia, yields clues to the riddle of mammoth hunting. Journal of Archaeological Science 40, 4189-4197. https://doi.org/10.1016/j.jas.2013.05.020

Nuzhnyi D., 1990. Projecile Damage on Upper Paleolithic Microliths and the Use of Bow and Arrow among Pleistocene Hunters in the Ukraine, in The Interpretative Possibibilties of Microwear Studies. Proceedings of the international conference on lithic use-wear analysis, 15th-17th February 1989 Uppsala, Sweden: Societas Archaeologia Upsaliensis, p. 113-124.

Nuzhnyj, D., 2007. Development of the Microlithic Technique in the Stone Age: Improvement of the Weapons of the Primitive Hunters, Second edition. ed. KNT Press, Kiev.

O'Farell, M., 2004. Les pointes de la Gravette de Corbiac (Dordogne) et considérations sur la chasse au Paléolithique supérieur ancien, in: Approches Fonctionnelles En Préhistoire. Actes Du XXVème Congrès Préhistorique de France, XXe Session. Provence 1974. pp. 121-138.

Peterson, M., 1951. Microlithen als Pfeilspitzen: ein fund aus dem Lilla Loshult-Moor, Ksp. Loshult, Skåne. Meddelande från Lunds universitets historia museum 1-15.

Pétillon, J.-M., 2016. Technological evolution of hunting implements among Pleistocene huntergatherers: Osseous projectile points in the middle and upper Magdalenian (19-14 ka cal BP). Quaternary International 414, 108-134. https://doi.org/10.1016/j.quaint.2015.08.063

Pétillon, J.-M., Bignon, O., Bodu, P., Cattelain, P., Debout, G., Langlais, M., Laroulandie, V., Plisson, H., Valentin, B., 2011. Hard core and cutting edge: experimental manufacture and use of Magdalenian composite projectile tips. Journal of Archeological Science 38, 1266-1283.

Philibert, S., 2002. Les derniers "Sauvages". Territoires économiques et systèmes techno-fonctionnels mésolithiques, BAR International Series. Oxford University Press, Oxford.

Plisson, H., 2005. Examen tracéologique des pointes aziliennes du Bois-Ragot, in: Chollet, A., Dujardin, V. (Eds.), La Grotte Du Bois-Ragot à Gouex (Vienne) : Magdalénien et Azilien: Essais Sur Les Hommes et Leurs Environnements, Mémoire de La Société Préhistorique Française. Paris, pp. 183-188.

Porraz, G., 2008. Middle palaeolithic mobile toolkits in short-term human occupations. Pié Lombard rockshelter (Provence, France) and Broion cave (Venetia, Italy): two case studies. Eurasian Prehistory 6, 33-56.

Porraz, G., Simon, P., Pasquini, A., 2010. Identité technique et comportements économiques des groupes proto-aurignaciens à la Grotte de l'Observatoire (Principauté de Monaco). Gallia préhistoire 52, 23-59. 
Porraz, G., Tomasso, A., Purdue, L., 2014. Les Prés de Laure, un premier site Paléolithique supérieur sur les terrasses de la moyenne vallée du Jabron (Var, France). Bulletin de la Société préhistorique française 111, 135-138.

Reimer, P.J., Bard, E., Bayliss, A., Warren Beck, J., Blackwell, P.G., Bronk Ramsey, C., Buck, C.E., Cheng, H., Edwards, R.L., Friedrich, M., Grootes, P.M., Guilderson, T.P., Haflidason, H., Hajdas, I., Hatté, C., Heaton, T.J., Hoffmann, D.L., Hogg, A.G., Hughen, K.A., Kaiser, K.F., Kromer, B., Manning, S.W., Niu, M., Reimer, R.W., Richards, D.A., Scott, E.M., Southon, J.R., Staff, R.A., Turney, C.S.M., van der Plicht, J., 2014. IntCal13 and Marine13 Radiocarbon Age Calibration Curves 0-50,000 Years cal BP. radiocarbon 55, 1869-1887.

Rots, V., 2016. Projectiles and Hafting Technology, in: Radu, I., Katsushiro, S. (Eds.), Multidisciplinary Approaches to the Study of Stone Age Weaponry, Vertebrate Paleobiology and Paleoanthropology. pp. 167-185.

Rots, V., 2013. Insights into early Middle Palaeolithic tool use and hafting in Western Europe. The functional analysis of level IIa of the early Middle Palaeolithic site of Biache-Saint-Vaast (France). Journal of Archaeological Science 40, 497-506.

Rots, V., 2010. Prehension and Hafting Traces on Flint Tools. A Methodology. Leuven University Press, Leuven.

Rots, V., 2002. Bright Spots and the Question of Hafting. Anthropologica et Praehistorica 113, 61-71.

Rots, V., Hayes, E., Cnuts, D., Lepers, C., Fullagar, R.L.K., 2016. Making sense of residues on flaked stone artefacts: learning from blind tests. PLoS ONE 11. https://doi.org/10.1371/journal. pone. 0150437

Rots, V., Lentfer, C., Schmid, V.C., Porraz, G., Conard, N.J., 2017. Pressure to serrate points for the hunt: Serrated points used as hafted projectiles at Sibudu Cave, South Africa. PLOS One.

Rots, V., Plisson, H., 2014. Projectiles and the abuse of the use-wear method in a search for impact. Journal of Archaeological Science 48, 154-165.

Rots, V., Van Peer, P., Vermeersch, P., 2011. Aspects of tool production, use, and hafting in Palaeolithic assemblages from Northeast Africa. Journal of Human Evolution 60, 637-664.

Soriano, S., 1998. Les microgravettes du Périgordien de Rabier à Lanquais (Dordogne) : analyse technologique fonctionnelle. Gallia préhistoire 40, 75-94. https://doi.org/doi:10.3406/galip.1998.2158

Straus, L.G., 1993. Upper Paleolithic hunting tactics and weapons in Western Europe, in: Peterkin, G.L., Bricker, H.M., Mellars, P. (Eds.), Hunting and Animal Exploitation in the Later Paleolithic and Mesolithic of Eurasia, Archeological Papers of the American Anthropological Association. pp. 83-93.

Svoboda, J.A., Hajnalova, M., Horacek, I., Novak, M., Prichytal, A., Sajnerova, A., Yaroshevich, A., 2007. Mesolithic settlement and activities in rockshelters of the Kamenice river canyon, Czech Republic. Eurasian Prehistory 5, 95-127.

Thieme, H., 1997. Lower Palaeolithic hunting spears from Germany. Nature 6, 139-142.

Tomasso, A., Binder, D., Martino, G., Porraz, G., Simon, P., 2016. Le référentiel Matières Premières de l'Arc Liguro-Provençal (MP-ALP): ressources siliceuses entre Vallée du Rhône et Apennins, in: Tomasso, A., Binder, D., Martino, G., Simon, P., Porraz, G., Naudinot, N. (Eds.), Ressources Lithiques, Productions et Transferts Entre Alpes et Méditerranée, Les Séances de La SPF, 5. Presented at the Séance décentralisée de la SPF, Nice 2013, Société Préhistorique Française, Nice, pp. 11-44.

Tomasso, S., Rots, V., 2017. What is the use of shaping a tang? Tool use and hafting of tanged tools in the Aterian of Northern Africa. Archaeological and Anthropological Sciences. https://doi.org/10.1007/s12520-016-0448-3

Van der Sluis, L.G., Hollund, H.I., Buckley, M., De Louw, P.G.B., Rijsdijk, K.F., Kars, H., 2014. Combining histology, stable isotope analysis and ZooMS collagen fingerprinting to investigate the taphonomic history and dietary behaviour of extinct giant tortoises from the Mare aux Songes deposit on Mauritius. Palaeogeography, Palaeoclimatology, Palaeoecology 416, 80-91. https://doi.org/10.1016/j.palaeo.2014.06.003

Vercoutère, C., Müller, K., Chiotti, L., Nespoulet, R., Staude, A., Riesemeier, H., Reiche, I., 2011. Rectangular Beads from the Final Gravettian Level of the Abri Pataud: Raw Material Identifi cation and its Archaeological Implications Les perles rectangulaires du Gravettien Final de 
l'abri Pataud: identifi cation de la matière première et ses implications archéologiques. ArchéoSciences, revue d'archéométrie 35, 259-271.

Weber, M.-J., 2012. From technology to tradition. Reevaluating the Hamburgian-Magdalenian relationship, Untersuchungen und Materialen zur Steinzeit in Schleswig-Holstein und im Ostseeraum. Neumünster, Wachholtz.

Yaroshevich, A., Nadel, D., Tsatskin, A., 2013. Composite projectiles and hafting technologies at Ohalo II (23 ka, Israel): analyses of impact fractures, morphometric characteristics and adhesive remains on microlithic tools. Journal of Archaeological Science 40, 4009-4023.

Zhilin, M., 2015. Early Mesolithic bon arrowheads from the volga-Oka interfluve, central Russia. Fennoscandia archaeologica 32. 